\title{
Changes in Ecophysiology, Osmolytes, and Secondary Metabolites of the Medicinal Plants of Mentha piperita and Catharanthus roseus Subjected to Drought and Heat Stress
}

\author{
Haifa A. Alhaithloul ${ }^{1}$, Mona H. Soliman ${ }^{2}$, Keshav Lalit Ameta ${ }^{3}$, Mohamed A. El-Esawi ${ }^{4} \mathbb{D}$ and \\ Amr Elkelish $5, *$ (i) \\ 1 Biology Department, College of Science, Jouf University, Sakaka 2014, Saudi Arabia; \\ Haifasakat2030@gmail.com \\ 2 Botany and Microbiology Department, Faculty of Science, Cairo University, Giza 12613, Egypt; \\ monahsh1@gmail.com \\ 3 Department of Chemistry, School of Liberal Arts and Sciences, Mody University of Science and Technology, \\ Lakshmangarh 332311, Rajasthan, India; klameta77@hotmail.com \\ 4 Botany Department, Faculty of Science, Tanta University, Tanta 31527, Egypt; \\ mohamed.elesawi@science.tanta.edu.eg \\ 5 Botany Department, Faculty of Science, Suez Canal University, Ismailia 41522, Egypt \\ * Correspondence: amr.elkelish@science.suez.edu.eg; Tel.: +20-100-514-5454
}

Received: 15 November 2019; Accepted: 24 December 2019; Published: 27 December 2019

\begin{abstract}
Global warming contributes to higher temperatures and reduces rainfall for most areas worldwide. The concurrent incidence of extreme temperature and water shortage lead to temperature stress damage in plants. Seeking to imitate a more natural field situation and to figure out responses of specific stresses with regard to their combination, we investigated physiological, biochemical, and metabolomic variations following drought and heat stress imposition (alone and combined) and recovery, using Mentha piperita and Catharanthus roseus plants. Plants were exposed to drought and/or heat stress $\left(35^{\circ} \mathrm{C}\right)$ for seven and fourteen days. Plant height and weight (both fresh and dry weight) were significantly decreased by stress, and the effects more pronounced with a combined heat and drought treatment. Drought and/or heat stress triggered the accumulation of osmolytes (proline, sugars, glycine betaine, and sugar alcohols including inositol and mannitol), with maximum accumulation in response to the combined stress. Total phenol, flavonoid, and saponin contents decreased in response to drought and/or heat stress at seven and fourteen days; however, levels of other secondary metabolites, including tannins, terpenoids, and alkaloids, increased under stress in both plants, with maximal accumulation under the combined heat/drought stress. Extracts from leaves of both species significantly inhibited the growth of pathogenic fungi and bacteria, as well as two human cancer cell lines. Drought and heat stress significantly reduced the antimicrobial and anticancer activities of plants. The increased accumulation of secondary metabolites observed in response to drought and/or heat stress suggests that imposition of abiotic stress may be a strategy for increasing the content of the therapeutic secondary metabolites associated with these plants.
\end{abstract}

Keywords: secondary metabolites; drought; heat stress; Mentha piperita; Catharanthus roseus

\section{Introduction}

One of the biggest issues concerning the impact of climate change on human being and natural ecosystems is the reaction of the Earth's hydrologic cycle to global warming [1,2]. As sessile species, 
plants are exposed to unavoidable drought and heat stress, which leads to growth and yield reductions in important crop plants [3]. The ongoing effects of climate change are expected to increase the frequency of drought and heat extremes, and the combined effects of these stresses are predicted to be more damaging than their individual effects [3]. Plants experience drought either due to low rainfall or less availability of water in the soil [4], and the intensity of drought is exacerbated by increases in temperature. Plants can endure periods of low water availability and high temperature by two strategies: avoidance and tolerance $[5,6]$. Some tolerance mechanisms are specific to a particular stress, while others are commonly initiated in response to variety of stresses. Examples of the latter mechanism are the accumulations of different metabolites, especially amino acids and sugars [7,8].

Stress mitigation responses are complex processes involving several factors, including sensing and signaling mediated by transcription factors, modulation of hormonal levels, and production of secondary metabolites [7,9]. Secondary metabolites are of particular interest, as they have important functions in regulating plant environmental interactions and subsequent adaptation responses [10-12]. Enhanced synthesis of phenylpropanoid metabolites like scopolin, sinapic acid, sinapoyl aldehyde, and flavonoids contribute to the synthesis of important structural compounds like lignins, but they also reduce oxidative damage and prevent photoinhibition by contributing to the antioxidant potential under abiotic stresses like drought and heat $[13,14]$.

Plant secondary metabolites also exhibit remarkable biological activities in non-plant species and are used as medicines and food additives due to their aromatic, therapeutic, and culinary properties. However, their synthesis and accumulation is complicated and is influenced by many different genetic, morphogenic, and environmental factors [12,15-17]. For this reason, the observation that abiotic stress induces changes in the synthesis of secondary metabolites suggests that the imposition of a stress may be a strategy for enhancing the therapeutic properties of many medicinal plant species [18,19]. However, the success of this strategy would depend on establishing a balance between the synthesis of the medicinal substances of interest and the synthesis of the other stress metabolites needed by the plant to tolerate the stress [20,21]. Ecophysiological studies must therefore also be part of this strategy, but the ecophysiology of stress responses in medicinal plants has received little attention [22].

Two important medicinal plants are peppermint (Mentha piperita) and Madagascar periwinkle (Catharanthus roseus). Mentha piperita, a popular herb in the Lamiaceae family, is cultivated for its flavoring and fragrance properties and is used in the production of food, cosmeceuticals, personal hygiene products, and other pharmaceutical products [23,24]. Peppermint oil has therapeutic properties and is used in aromatherapy, mouthwashes, and toothpastes. It is also an active ingredient in several topical preparations used to calm pruritus and relieve irritation and inflammation [23]. Key components of peppermint oil are menthol and menthone, with lesser concentrations of pulegone, menthofuran, and limone [24]. Catharanthus roseus is an important medicinal and ornamental plant from the Apocynaceae and is a key source of the anticancer drugs vincristine and vinblastine, as well as nearly seventy other alkaloids [25]. However, the responses of these two medicinal plants to abiotic stresses are unknown.

The aims of the present study were therefore to document the ecophysiological responses of M. piperita and C. roseus to drought and/or heat stress and to assess any stress-related changes in osmolytes and secondary metabolites. A secondary goal was to confirm the medicinal activities of aqueous and methanolic extracts from these plants against pathogenic bacteria, fungi, and cancer cells. The findings indicate that exposure of C. roseus and $M$. piperita to abiotic stress (heat and/or drought) redirects plant metabolism in a manner that could potentially increase the synthesis of the therapeutic secondary metabolites that could have antimicrobial and in vitro anticancer activity. 


\section{Materials and Methods}

\subsection{Pot Experiments}

Sterilized seeds of Mentha piperita (peppermint) and Catharanthus roseus (Cape periwinkle) were sown in plastic pots $(19 \mathrm{~cm}$ in diameter $\times 17 \mathrm{~cm}$ in depth) filled with a 5:1 $(v / v)$ mixture of clay soil and peat. After germination, the seedlings were well-watered until the age of 45 (M. piperita) or 60 (C. roseus) days. Thereafter, plants were subjected to heat and/or drought stress for seven and fourteen days. Pots were kept in a greenhouse maintained at $65 \%$ humidity and a $12 \mathrm{~h}$ photoperiod. Therefore, we had following set of treatments:

Control: Plants grown under normal $\left(17-22^{\circ} \mathrm{C}\right)$ temperature and normal irrigation.

Heat stress $(\mathrm{H})$ : Plants grown at high temperature $\left(35^{\circ} \mathrm{C}\right)$.

Drought stress (D): 50\% drought stress imposed by the cessation of watering for 2 weeks.

Drought and heat stress $(\mathrm{H}+\mathrm{D})$ : This combined stress occurred at the same time and imposed by transferring the plants to high temperature $\left(35^{\circ} \mathrm{C}\right)$ as well as cessation of watering for 2 weeks.

\subsection{Seedling Growth Measurements}

Morphological traits of treated and untreated of M. piperita and C. roseus plants were measured. Five plants with roots were harvested and transferred to the laboratory for measuring plant height; shoot and root fresh weight. Shoot and root dry weights were measured after drying in the shade at room temperature for $72 \mathrm{~h}$.

\subsection{Biochemical Assays}

\subsubsection{Total Soluble Proteins}

Fresh leaves $(0.5 \mathrm{~g})$ of $M$. piperita and $C$. roseus harvested at 7 and 14 days from all treatments were ground in $1 \mathrm{~mL}$ of phosphate buffer $(0.1 \mathrm{M}, \mathrm{pH} 7.0)$ and kept in ice. The protein concentration was determined following Bradford assay [26]. Absorbance was read at $595 \mathrm{~nm}$ on a spectrophotometer.

\subsubsection{Proline Content}

Proline was measured according to Troll and Lindsley [27] with slight modification. Samples (100 mg fresh weight) of M. piperita and C. roseus leaves were harvested at 7 and 14 days, ground in liquid nitrogen, homogenized in 5\% (w/v) sulfosalicylic acid and centrifuged at 14,000× $g$ for $5 \mathrm{~min}$. The supernatants were mixed with $2 \mathrm{~mL} \mathrm{40 \%} \mathrm{methanol,} \mathrm{and} \mathrm{heated} \mathrm{at} 95^{\circ} \mathrm{C}$ in water bath for $60 \mathrm{~min}$. After cooling, $1 \mathrm{~mL}$ of extract was added to $1 \mathrm{~mL}$ of acetic acid and $1 \mathrm{~mL}$ of a mixture containing $120 \mathrm{~mL}$ distilled water and $300 \mathrm{~mL}$ phosphoric acid. The samples were boiled for $30 \mathrm{~min}$, cooled, and then $5 \mathrm{~mL}$ of toluene was added. The upper phase was recovered, and the absorbance was measured at $528 \mathrm{~nm}$. The proline concentration was estimated from a standard curve.

\subsubsection{Glycine Betaine}

A $0.5 \mathrm{~g}$ sample of $M$. piperita or C. roseus leaves harvested at 7 and 14 days was homogenized with $10 \mathrm{~mL}$ of Milli-Q Water and was incubated for $24 \mathrm{~h}$ at $25^{\circ} \mathrm{C}$. The homogenate was filtered, and the filtrate was mixed with $2 \mathrm{~N}$ sulfuric acid at a ratio of $1: 1(v: v)$. This mixture $(0.5 \mathrm{~mL})$ was placed on ice for $1 \mathrm{~h}$ and then $0.2 \mathrm{~mL}$ of cold potassium tri-iodide reagent was added. After storage at $4{ }^{\circ} \mathrm{C}$ for $16 \mathrm{~h}$, the mixture was centrifuged at $14,000 \mathrm{rpm}$ for $15 \mathrm{~min}$ at $0{ }^{\circ} \mathrm{C}$. Absorbance of the supernatant was read at $365 \mathrm{~nm}$. The glycine betaine concentration was estimated from a standard curve [28]. 


\subsection{Phytochemical Assays}

\subsubsection{Total Soluble Sugars}

Total soluble sugars (TSS) were extracted from M. piperita and C. roseus leaves at 7 and 14 days for all stress treatments using the method of Irigoyen et al. [29]. A sample (0.2 g) of dried leaves was homogenized in $5 \mathrm{~mL}$ of $96 \%(v / v)$ ethanol and washed with $5 \mathrm{~mL}$ of $70 \%(v / v)$ ethanol. The extract was centrifuged at $3500 \times g$ for $10 \mathrm{~min}$, and the supernatant was stored at $4{ }^{\circ} \mathrm{C}$ prior to measurement. Each TSS concentration was determined by reacting $0.1 \mathrm{~mL}$ of the ethanolic extract with $3 \mathrm{~mL}$ of freshly prepared anthrone reagent ( $150 \mathrm{mg}$ anthrone plus $100 \mathrm{~mL}$ of $72 \%$ sulfuric acid) by placing it in a boiling water bath for $10 \mathrm{~min}$. After cooling, the mixture absorbance was recorded at $625 \mathrm{~nm}$.

\subsubsection{Mannitol and Inositol Contents}

The mannitol content in stressed and unstressed M. piperita and C. roseus plant leaves was determined using a Mannitol Colorimetric Assay kit (Sigma-Aldrich, Munich, Germany) and measuring the absorbance at $450 \mathrm{~nm}$. The inositol content in control and stressed M. piperita and C. roseus leaves were measured with a Myo-Inositol Assay kit (BioVision, Inc., San Francisco, CA, USA).

\subsubsection{Total Phenolic Content (TPC)}

The total phenolic content (TPC) was estimated in fresh samples of the uppermost leaves in M. piperita and C. roseus following the protocol of Slinkard and Singleton [30]. After extraction with ethanol $(80 \%, v / v)$, the supernatant was reacted with Folin and Ciocalteau's reagent [31] and the optical density of the mixture was read at $750 \mathrm{~nm}$. The concentrations were estimated from a standard curve of pyrogallol.

\subsubsection{Total Flavonoid Content (TFC)}

The total flavonoid content (TFC) was estimated according to Zhishen et al. [32] using catechin as a standard. Samples were extracted in methanol and the absorbance was recorded at $510 \mathrm{~nm}$. The flavonoid content was expressed as mg per $g$ fresh weight (FW).

\subsubsection{Saponins}

Saponins were determined according to the method of Obadoni and Ochuko [33]. A $10 \mathrm{~g}$ sample of air-dried M. piperita or C. roseus leaf material was put into a conical flask containing $50 \mathrm{~mL}$ of $20 \%$ aqueous ethanol. The samples were heated over a hot water bath at about $55{ }^{\circ} \mathrm{C}$ for $4 \mathrm{~h}$ with continuous stirring. The mixture was filtered, and the residue was re-extracted with another $100 \mathrm{~mL}$ of $20 \%$ ethanol. The combined extracts were reduced to $20 \mathrm{~mL}$ over a water bath at about $90{ }^{\circ} \mathrm{C}$. The concentrate was transferred into a $250 \mathrm{~mL}$ separating funnel and $10 \mathrm{~mL}$ of diethyl ether was added and shaken vigorously. The aqueous layer was recovered, and the ether layer was discarded. The purification process was repeated, and then $30 \mathrm{~mL}$ of $\mathrm{n}$-butanol was added. The combined n-butanol extracts were washed twice with $10 \mathrm{~mL}$ of $5 \%$ aqueous sodium chloride and heated in a water bath. After evaporation, the samples were dried in an oven to a constant weight and the saponin content was calculated as percentage.

\subsubsection{Terpenoids}

Total terpenoids were estimated by the protocol of Ferguson [34]. A $10 \mathrm{~g}$ sample of air-dried M. piperita or C. roseus leaf material was soaked in alcohol for $24 \mathrm{~h}$ and then filtered. The filtrate was extracted with petroleum ether, and the ether extract was treated as the total terpenoid extract. 


\subsubsection{Tannins}

Tannins were determined as described previously [35,36]. A $1 \mathrm{~g}$ sample of powdered air-dried leaf from M. piperita and C. roseus was placed in a conical flask can combined with $100 \mathrm{~mL}$ of distilled water. This was boiled gently for $1 \mathrm{~h}$ on an electric hot plate and then filtered through Whatman 42 filter paper $(125 \mathrm{~mm})$ into a $100 \mathrm{~mL}$ volumetric flask. A $5.0 \mathrm{~mL}$ volume of Folin-Denis reagent and $10 \mathrm{~mL}$ of saturated $\mathrm{Na}_{2} \mathrm{CO}_{3}$ solution were added to $50 \mathrm{~mL}$ of distilled water in a $100 \mathrm{~mL}$ conical flask, and $10 \mathrm{~mL}$ of diluted extract was added for color development. The solution was left to react for $30 \mathrm{~min}$ in a water bath at $25^{\circ} \mathrm{C}$ after thorough agitation. Optical density was read at $700 \mathrm{~nm}$ and compared against a standard curve of tannic acid:

$$
\text { Tannic acid }(\mathrm{mg} / 100 \mathrm{~g})=\frac{C \times \text { extract volume } \times 100}{\text { Aliquot volume } \times \text { weight of sample }}
$$

where $C$ is the concentration of tannic acid read off the graph.

\subsubsection{Alkaloids}

Alkaloids were determined according to Harborne [37]. A $5 \mathrm{~g}$ sample of air-dried M. piperita or C. roseus leaf was weighed into a $250 \mathrm{~mL}$ beaker, $200 \mathrm{~mL}$ of $10 \%$ acetic acid in ethanol was added, and the beaker was covered and allowed to stand for $4 \mathrm{~h}$. The solution was filtered, and the extract was concentrated on a water bath to one-quarter of the original volume. Concentrated ammonium hydroxide was added dropwise to the extract until precipitation was complete. The whole solution was allowed to settle, and the precipitate was collected and washed with dilute ammonium hydroxide and then filtered. The residue, which was designated as the total alkaloids, was dried and weighed.

\subsection{Antioxidant Assays}

\subsubsection{Preparation of the Aqueous and Methanolic Extracts}

A $10 \mathrm{~g}$ sample of air-dried aerial parts (dried for one week at room temperature) from healthy M. piperita or C. roseus plants was ground to a fine powder. A $5 \mathrm{~g}$ sample of the powder was then extracted overnight in $10 \mathrm{~mL}$ of distilled water or pure methanol. The extracts were filtered through Whatman No. 1 filter paper and stored at $4{ }^{\circ} \mathrm{C}$.

\subsubsection{DPPH Scavenging Activities of M. piperita and C. roseus Extracts}

Total antioxidant capacity was measured by determining the 2,2-diphenyl-1-picrylhydrazyl (DPPH) scavenging activity of aqueous and methanolic extracts $(50 \mathrm{mg} / \mathrm{mL})$ of M. piperita and C. roseus according to Espin et al. [38] with slight modifications. Dried plant extract was diluted in pure methanol at different concentrations, and $2 \mathrm{~mL}$ were added to $0.5 \mathrm{~mL}$ of a $0.2 \mathrm{mM}$ DPPH methanolic solution. The mixture was shaken vigorously and left to stand at room temperature for $30 \mathrm{~min}$. The absorbance of the resulting solution was then measured at $517 \mathrm{~nm}$ measured after $30 \mathrm{~min}$.

$$
\text { Antioxidant activity } \%=\frac{(\text { Absorbance Control }- \text { Absorbance Sample }) \times 100}{\text { Absorbance Control }}
$$

\subsection{Determination of Antimicrobial Activity}

\subsubsection{Antibacterial Activities of M. piperita and C. roseus Extracts}

The antibacterial activity of different concentrations ( $10 \%$ and $20 \%)$ of the aqueous and methanolic extracts of M. piperita and C. roseus were evaluated against Pseudomonas aeruginosa, Staphylococcus aureus and Ralstonia solanacearum using the agar well diffusion method. Autoclaved agar plates were inoculated with bacterial cell suspensions and wells $(5 \mathrm{~mm})$ were made in each agar plate using a sterile metallic borer. Each well was loaded with $25 \mu \mathrm{L}$ of extract or ampicillin $(0.2 \mu \mathrm{g} / \mathrm{mL})$ as positive 
control. All the plates were incubated at $37^{\circ} \mathrm{C}$ for $48 \mathrm{~h}$, and the results were expressed as the size of the zone of inhibition.

\subsubsection{Antifungal Activities of $M$. piperita and C. roseus Extracts}

The antifungal activity of different concentrations $(0.5 \%$ and $1.0 \% ; v / v)$ of $M$. piperita and C. roseus aqueous and methanolic extracts were investigated against the plant pathogenic fungi Fusarium oxysporum and Aspergillus terreus by the agar well diffusion method. The chemical fungicide Rhizolex-T (20 ppm) was used as a positive control. Agar medium was poured into 90-mm Petri dishes and inoculated with a 5-mm disk of Fusarium oxysporum and Aspergillus culture. Five replicates (dishes) were used for each treatment concentration and control, and the dishes were incubated at $25^{\circ} \mathrm{C}$ for $5-7$ days. The reduction in mycelial growth was calculated as percentage of the control fungal growth.

\subsection{Cytotoxic and Anticancer Activities of M. piperita and C. roseus Extracts}

Cytotoxicity against the PC3 human prostate cancer and the MCF-7 human breast cancer lines was measured in vitro using the 3-(4,5-dimethylthiazol-2-yl)-2,5-diphenyltetrazolium bromide (MTT) assay, as described by Romijn et al. [39]. Cells were exposed to different concentrations (50, and 100 $\mu \mathrm{g} / \mathrm{mL}$ ) of M. piperita and C. roseus aqueous and methanolic extracts by plating in triplicate in 96-well plates in serum-free media containing either plant extract or 5-fluorouracil $(20 \mu \mathrm{g} / \mathrm{mL}$; positive control). After incubation at $37^{\circ} \mathrm{C}$ for $72 \mathrm{~h}, 20 \mu \mathrm{L}$ of MTT solution was added, the cells were incubated for $3 \mathrm{~h}$, and the absorbance was read at $570 \mathrm{~nm}$ in a multi-mode plate reader (BioTek, Bad Friedrichshall, Heilbronn, Germany). The anticancer activity of the extract was calculated using the following formula:

$$
\text { Inhibition } \%=\frac{100-\text { optical density of sample } \times 100}{\text { Optical density of control }}
$$

\subsection{Statistical Analysis}

Data are the means \pm standard error (SE). Analysis of variance (ANOVA) was carried out using SPSS version 19 (SPSS Inc., Chicago, IL, USA). Tukey's test was conducted to test the significance between mean values $(p<0.05)$.

\section{Results and Discussion}

3.1. Effects of Drought and Heat Stress on the Growth and Physiological and Metabolomic Traits of M. piperita and $C$. roseus

Drought and heat stress frequently co-occur, especially in arid and semi-arid regions of globe, and they result in significant decreases in plant growth and productivity [40,41]. Plants frequently survive these stress conditions by changing their metabolism to favor the synthesis of osmolytes and secondary metabolites that promote stress tolerance. Previous studies on drought [42] and heat stress $[43,44]$ in crop plants like wheat and Lens culinaris have demonstrated significant reductions in growth and development due to damage to cell membranes and disruption of photosynthesis and water relations. However, the ecophysiological and metabolic responses of important medicinal plants to abiotic stress have received little attention. The present study was prompted by this gap in knowledge.

The present findings confirm that both M. piperita and C. roseus show typical growth responses to abiotic stress, including decreases in plant height and in fresh and dry weight, and that the effects are most pronounced in seedlings exposed to a combined heat and drought stress (Tables 1 and 2). The maximum declines in height and fresh and dry weight in the shoot were $28.99,44.88$, and $45.45 \%$ in M. piperita and $48.63,33.68$, and $42.58 \%$ in C. roseus following exposure to a combined heat and drought stress. No significant differences were observed in the root fresh and dry weight in the stressed plants when compared to control plants (Tables 1 and 2). 
Drought and heat stress restrict the uptake and assimilation of nutrients, while favoring amino acid accumulation, resulting in significant effects on plant growth and development $[45,46]$. High temperatures also alter cell growth and proliferation by influencing the cell cycle progression and hence cell division [47]. Growth inhibition triggered by extreme environmental conditions has been associated with up-regulation and down-regulation of cell cycle inhibitors and stimulators [48]. Plants are able to tolerate abiotic stress and to prevent some of the stress-mediated retardation of growth and development by accumulating specific organic and inorganic osmolytes, including proline, glycine betaine, sugars, and sugar alcohols like inositol and mannitol [5].

Table 1. Effect of drought, heat and drought + heat stress on the height of M. piperita and C. roseus after seven and fourteen days of stress exposure.

\begin{tabular}{cccc}
\hline \multirow{2}{*}{ Plant } & Treatments & \multicolumn{2}{c}{ Height (cm) } \\
\cline { 3 - 4 } & & $54.8 \pm 0.42 \mathrm{a}$ & $61.4 \pm 0.61 \mathrm{a}$ \\
& Control & $44.9 \pm 0.10 \mathrm{bc}$ & $53.6 \pm 0.26 \mathrm{~b}$ \\
M. piperitas & Drought & $47.6 \pm 0.19 \mathrm{~b}$ & $55.4 \pm 0.30 \mathrm{~b}$ \\
& Heat & $36.6 \pm 0.28 \mathrm{~d}$ & $43.6 \pm 0.02 \mathrm{c}$ \\
\hline \multirow{4}{*}{ C. roseus } & Drought + Heat & $35.2 \pm 0.27 \mathrm{~d}$ & $43.8 \pm 0.16 \mathrm{c}$ \\
& Control & $29.4 \pm 0.40 \mathrm{ef}$ & $34.3 \pm 0.20 \mathrm{e}$ \\
& Drought & $31.7 \pm 0.20 \mathrm{e}$ & $39.5 \pm 0.11 \mathrm{~d}$ \\
& Heat & $19.3 \pm 0.21 \mathrm{~g}$ & $22.5 \pm 0.26 \mathrm{f}$ \\
\hline
\end{tabular}

Mean $( \pm$ SE) of five values is presented and values denoted by different letters are significantly different at $p<0.05$.

In present study, both $M$. piperita and C. roseus accumulated significant amounts of proline, glycine betaine, sugar, inositol, and mannitol in response to drought and heat stress, with maximal accumulations observed in response to the combined drought and heat stress (Figures 1 and 2). The respective increases in proline, glycine betaine, sugar, inositol, and mannitol over the control values were $34.13,43.22,19.89,9.04$ and $21.71 \%$ in $M$. piperita and $42.34,31.17,12.93,70.87$ and $43.45 \%$ in C. roseus after 14 days of drought stress. Protein contents were increased maximally in response to the individual drought or heat stress exposures. These results could be attributed to the induction of genes involved in protein synthesis and heat shock proteins by the individual drought or heat stress. In contrast, the combined drought and heat stress reduced protein content which might be due to the increase in severity which in turn led to decreasing or inhibiting protein biosynthesis as well as down-regulation of heat shock proteins. Accumulation of all these osmolytes was maximal after fourteen days of stress exposure. Similar accumulations of osmolytes were also observed after 14 days of heat stress. The respective maximal accumulations were 55.09, 58.09, 17.25, 27.69 and $44.30 \%$ in M. piperita and 45.04, 46.77, 16.42, 77.97 and 50.68\% in C. roseus following the combined heat and drought stress (Figure 2).

Osmolytes help plants to avert the damaging effects of drought and heat stress by increasing the cellular water content to maintain the structural and functional integrity of cells [9,49]. The accumulation of osmolytes, even at high concentrations, does not affect cell function because of the compatible nature of these solutes [50,51]. Prominent osmolytes include a variety of amino acids, sulfonium and ammonium compounds, sugars, and polyhydric alcohols. Accumulation of compatible osmolytes prevents osmotic shock, protects enzyme activity, and ameliorates oxidative damage by scavenging stress-induced reactive oxygen species [49]. 
Table 2. Effect of drought, heat and drought + heat stress on the fresh and dry weight of shoot and root of M. piperita and C. roseus after seven and fourteen days of stress exposure.

\begin{tabular}{|c|c|c|c|c|c|c|c|c|c|}
\hline \multirow{2}{*}{ Plant } & \multirow{2}{*}{ Treatments } & \multicolumn{2}{|c|}{ Shoot FW (g) } & \multicolumn{2}{|c|}{ Root FW (g) } & \multicolumn{2}{|c|}{ Shoot DW (g) } & \multicolumn{2}{|c|}{ Root DW (g) } \\
\hline & & 7 Day & 14 Day & 7 Day & 14 Day & 7 Day & 14 Day & 7 Day & 14 Day \\
\hline \multirow{4}{*}{ M. piperita } & Control & $20.4 \pm 0.13 \mathrm{a}$ & $26.6 \pm 0.23 a$ & $8.4 \pm 0.032 \mathrm{a}$ & $9.1 \pm 0.06 \mathrm{a}$ & $1.2 \pm 0.026 \mathrm{a}$ & $1.7 \pm 0.028 \mathrm{a}$ & $0.6 \pm 0.013 a$ & $0.7 \pm 0.035 a$ \\
\hline & Drought & $12.4 \pm 0.31 c$ & $19.2 \pm 0.84 b$ & $6.3 \pm 0.012 b$ & $7.5 \pm 0.02 c$ & $0.9 \pm 0.017 c$ & $1.4 \pm 0.126 b$ & $0.5 \pm 0.017 \mathrm{~b}$ & $0.6 \pm 0.024$ \\
\hline & Heat & $17.1 \pm 0.24 b$ & $15.3 \pm 0.85 c$ & $6.7 \pm 0.14 b$ & $8.2 \pm 0.03 \mathrm{ab}$ & $1.1 \pm 0.011 b$ & $1.3 \pm 0.026 b$ & $0.4 \pm 0.023 \mathrm{~d}$ & $0.6 \pm 0.021 b$ \\
\hline & Drought + Heat & $10.3 \pm 0.14 \mathrm{~d}$ & $14.7 \pm 0.14 \mathrm{c}$ & $5.7 \pm 0.063 c$ & $6.4 \pm 0.033 \mathrm{~d}$ & $0.7 \pm 0.022 \mathrm{e}$ & $0.9 \pm 0.066 c$ & $0.5 \pm 0.022 b c$ & $0.5 \pm 0.023 \mathrm{~d}$ \\
\hline \multirow{4}{*}{ C. roseus } & Control & $11.4 \pm 0.61 \mathrm{~cd}$ & $12.3 \pm 0.18 \mathrm{~d}$ & $4.1 \pm 0.044 \mathrm{~d}$ & $6.2 \pm 0.02 \mathrm{~d}$ & $1.1 \pm 0.051 b$ & $1.4 \pm 0.44 \mathrm{~b}$ & $0.5 \pm 0.016 \mathrm{~b}$ & $0.5 \pm 0.012 \mathrm{~d}$ \\
\hline & Drought & $7.2 \pm 0.25$ ef & $9.3 \pm 0.13 \mathrm{f}$ & $3.6 \pm 0.033 \mathrm{e}$ & $4.8 \pm 0.01 \mathrm{e}$ & $0.7 \pm 0.028 \mathrm{e}$ & $0.8 \pm 0.026 \mathrm{~d}$ & $0.3 \pm 0.024 \mathrm{~d}$ & $0.3 \pm 0.024 \mathrm{f}$ \\
\hline & Heat & $8.1 \pm 0.61 \mathrm{e}$ & $10.6 \pm 0.07 \mathrm{e}$ & $3.8 \pm 0.065 \mathrm{e}$ & $5.1 \pm 0.05 \mathrm{e}$ & $0.8 \pm 0.028 \mathrm{~d}$ & $0.8 \pm 0.031 \mathrm{~d}$ & $0.4 \pm 0.023 \mathrm{~d}$ & $0.4 \pm 0.014 \mathrm{e}$ \\
\hline & Drought + Heat & $5.1 \pm 0.45 \mathrm{~g}$ & $8.1 \pm 0.06 \mathrm{fg}$ & $2.8 \pm 0.082 \mathrm{f}$ & $3.2 \pm 0.07 \mathrm{f}$ & $0.7 \pm 0.017 \mathrm{e}$ & $0.8 \pm 0.035 \mathrm{~d}$ & $0.3 \pm 0.017 \mathrm{f}$ & $0.3 \pm 0.022 \mathrm{~g}$ \\
\hline
\end{tabular}

Mean ( \pm SE) of five values is presented and values denoted by different letters are significantly different at $p<0.05$. FW denotes fresh weight; DW denotes dry weight. 

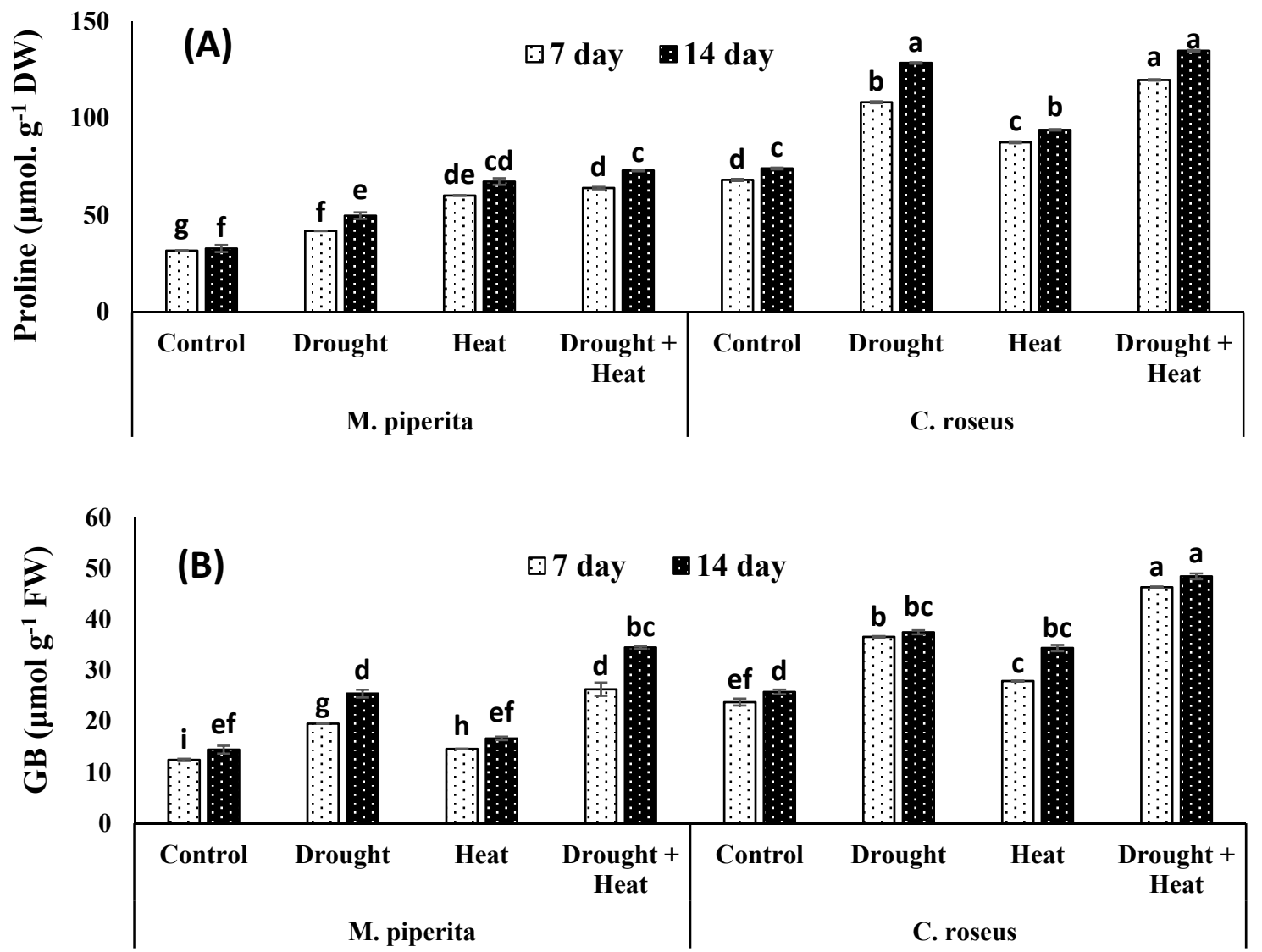

Figure 1. Effect of drought, heat and drought + heat stress on the proline (A) and glycine betaine (B) of M. piperita and C. roseus after seven and fourteen days of stress exposure. Mean $( \pm \mathrm{SE})$ of five values is presented and values denoted by different letters are significantly different at $p<0.05$.

Proline accumulation alleviates cytoplasmic acidosis and maintains the NADP+/NAD+ ratio [52]. Excess proline also serves as a sink for excess reductants and assists in photosynthesis and respiration by increasing the availability of NADP and NAD. Increases in glycine betaine or proline can also prevent photoinhibition by maintaining the carboxylase activity of Rubisco [53,54]. Increases in NADP maintain the operation of the pentose phosphate pathway, leading to a greater generation of NADPH and a supply of the ribose-5-phosphate substrate required for purine synthesis $[55,56]$. Increased accumulation of proline and sugars under drought stress has been reported in maize [57] and wheat [8], and combined exposure to drought and heat stress increased the accumulation of sugars in Lens culinaris [46]. Increased accumulation of osmolytes is a direct result of the up-regulation of their biosynthesis and down-regulation of their catabolic pathways, as reported for proline metabolism in Brassica juncea [58]. In Vigna aconitifolia, Harsh et al. [59] have reported that the increased accumulation of proline and sugars in response to heat stress reflects a greater antioxidant potential. In Cicer arietinum L., increased accumulation of proline during heat stress has been reported to protect the functioning of major enzymes like Rubisco and enzymes involved in sugar metabolism, including sucrose phosphate synthase and invertase [60]. Plants that accumulate proline, trehalose, fructans, mannitol, or glycine betaine exhibit improved stress tolerance [52,61-63].

Sugars display hormone-like activities and can function as primary messengers in signaling. Sugar-mediated signaling controls growth and developmental events; consequently, high concentrations of accumulated sugars may reflect undesirable growth conditions during early seedling development [64], whereas their accumulation at later growth stages has been reported to improve cellular and whole plant functioning under both normal and stress conditions [42]. Increased accumulation of sugars and other osmolytes contributes to growth regulation under stress conditions by elimination of reactive oxygen species (ROS) through a strengthened antioxidant 
system $[65,66]$. In the present study, soluble sugars were enhanced under drought and heat stress, which might be attributed to the enhancement of glucose and fructose as a result of increasing the hydrolysis of the sucrose and starch. Soluble sugars might do other numerous cellular and nutritional functions as an energy source and osmoprotectants which protect the plants under stress conditions.
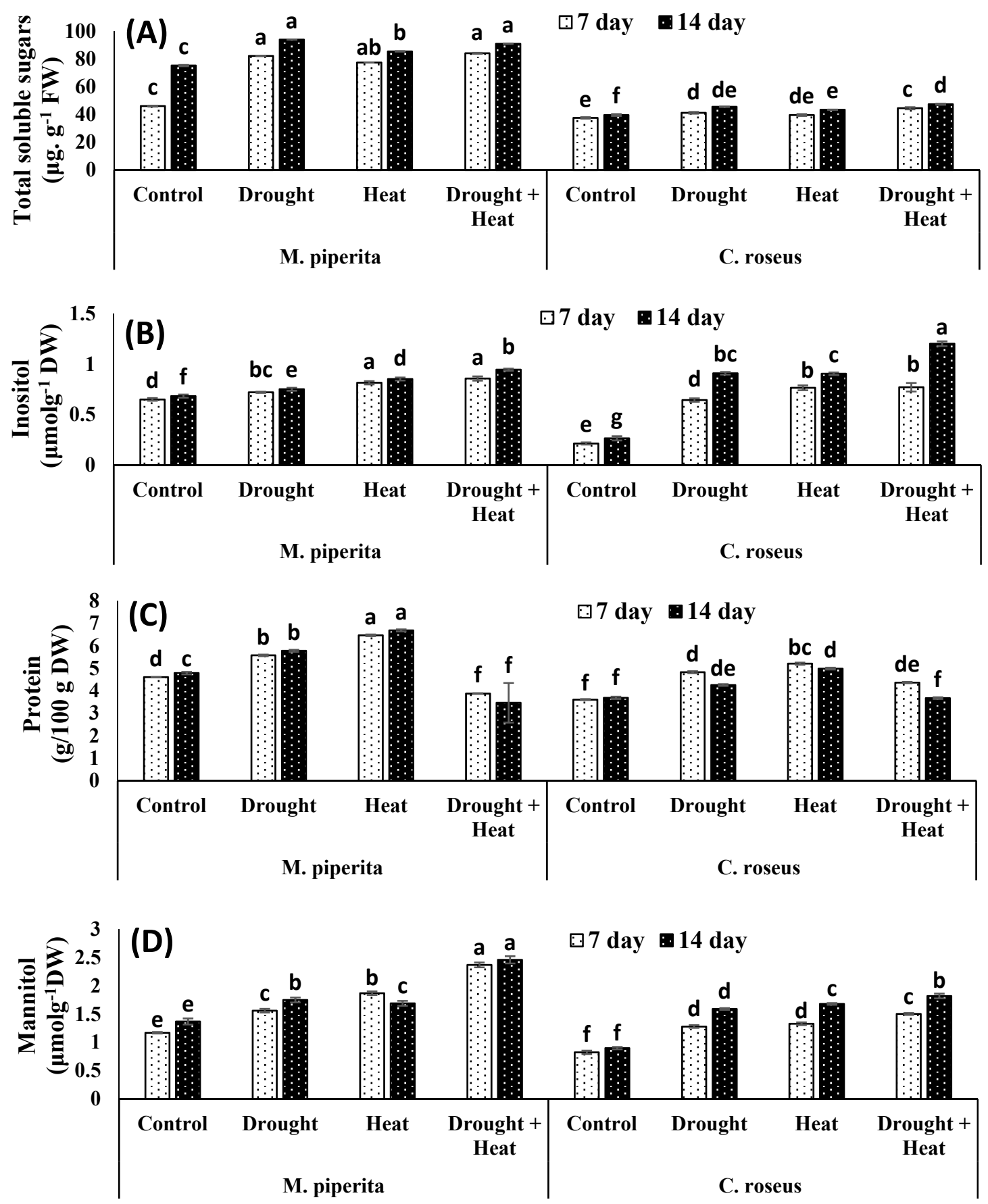

Figure 2. Effect of drought, heat and drought + heat stress on the total soluble sugars (A), inositol (B), protein (C) and mannitol (D) of M. piperita and C. roseus after seven and fourteen days of stress exposure. Mean $( \pm \mathrm{SE})$ of five values is presented and values denoted by different letters are significantly different at $p<0.05$.

Drought and heat stress had differential effects on the accumulation of secondary metabolites. Total phenols, flavonoids, saponins and DPPH scavenging activities underwent significant declines in response to drought and heat stress, whereas terpenoid, alkaloid, and tannin levels increased, with the 
greatest increase seen in plants exposed to the combined stress (Figures 3 and 4). After fourteen days of the combined stress, total phenols, flavonoids, and saponins showed respective decreases of $22.51,32.55$, and $15.96 \%$ in M. piperita and $22.13,40.51$, and $92.99 \%$ in C. roseus. The maximal declines of $39.29 \%$ and $48.67 \%$ for total phenols and $39.14 \%$ and $42.37 \%$ for flavonoids in M. piperita and $C$. roseus, respectively, were observed in heat-stressed plants after fourteen days of stress exposure (Figures 3 and 4). The drought-stressed M. piperita and C. roseus plants showed respective declines of $21.46 \%$ and $29.57 \%$ in total phenols, $37.57 \%$ and $39.96 \%$ in flavonoids, and $17.95 \%$ and $66.20 \%$ in saponins (Figures 3 and 4), whereas tannins, alkaloids, and terpenoids increased in both species due to drought stress. The maximal increases were $29.14 \%$ and $50.16 \%$ for tannins, $39.39 \%$ and $53.72 \%$ for alkaloids, and $6.59 \%$ and $36.11 \%$ terpenoids in M. piperita and C. roseus, respectively, following exposure to the combined stress.
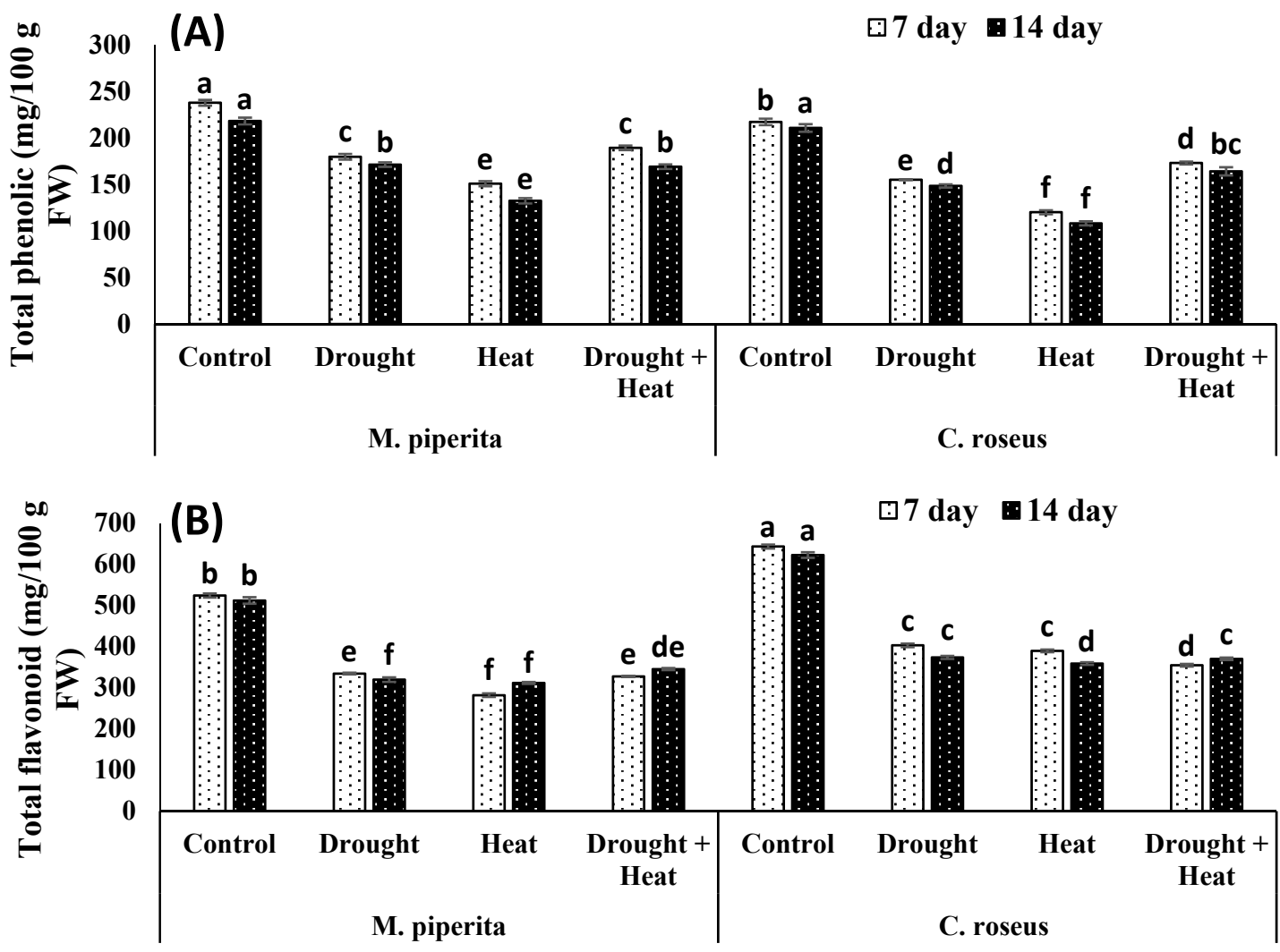

(C)

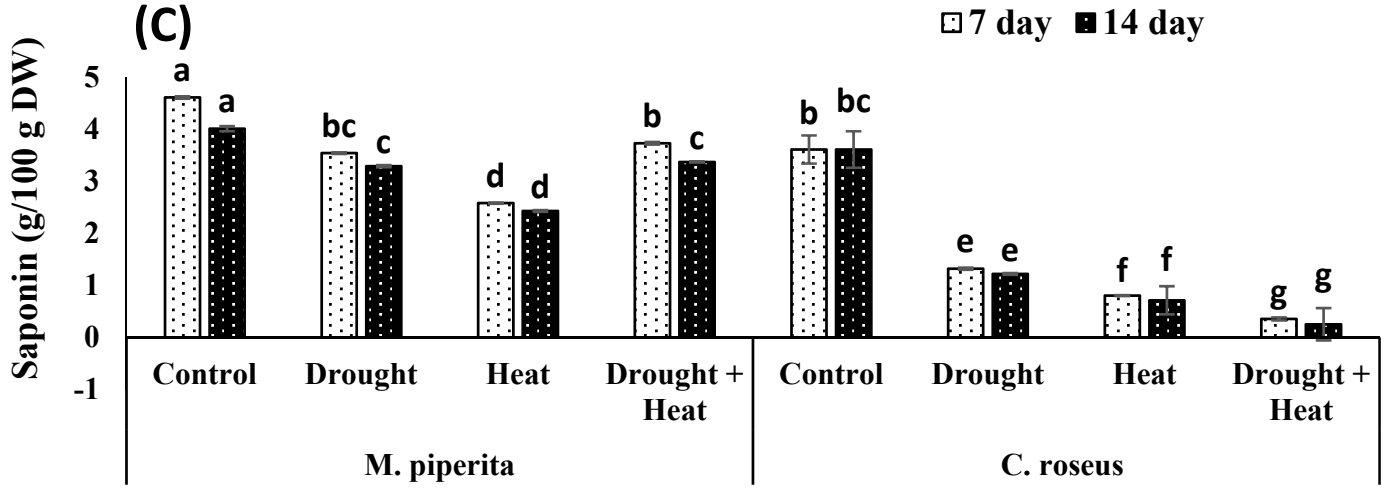

Figure 3. Effect of drought, heat and drought + heat stress on the total phenols (A), total flavonoids (B) and saponins (C) in M. piperita and C. roseus after seven and fourteen days of stress exposure. Mean $( \pm$ SE) of five values is presented and values denoted by different letters are significantly different at $p<0.05$. 

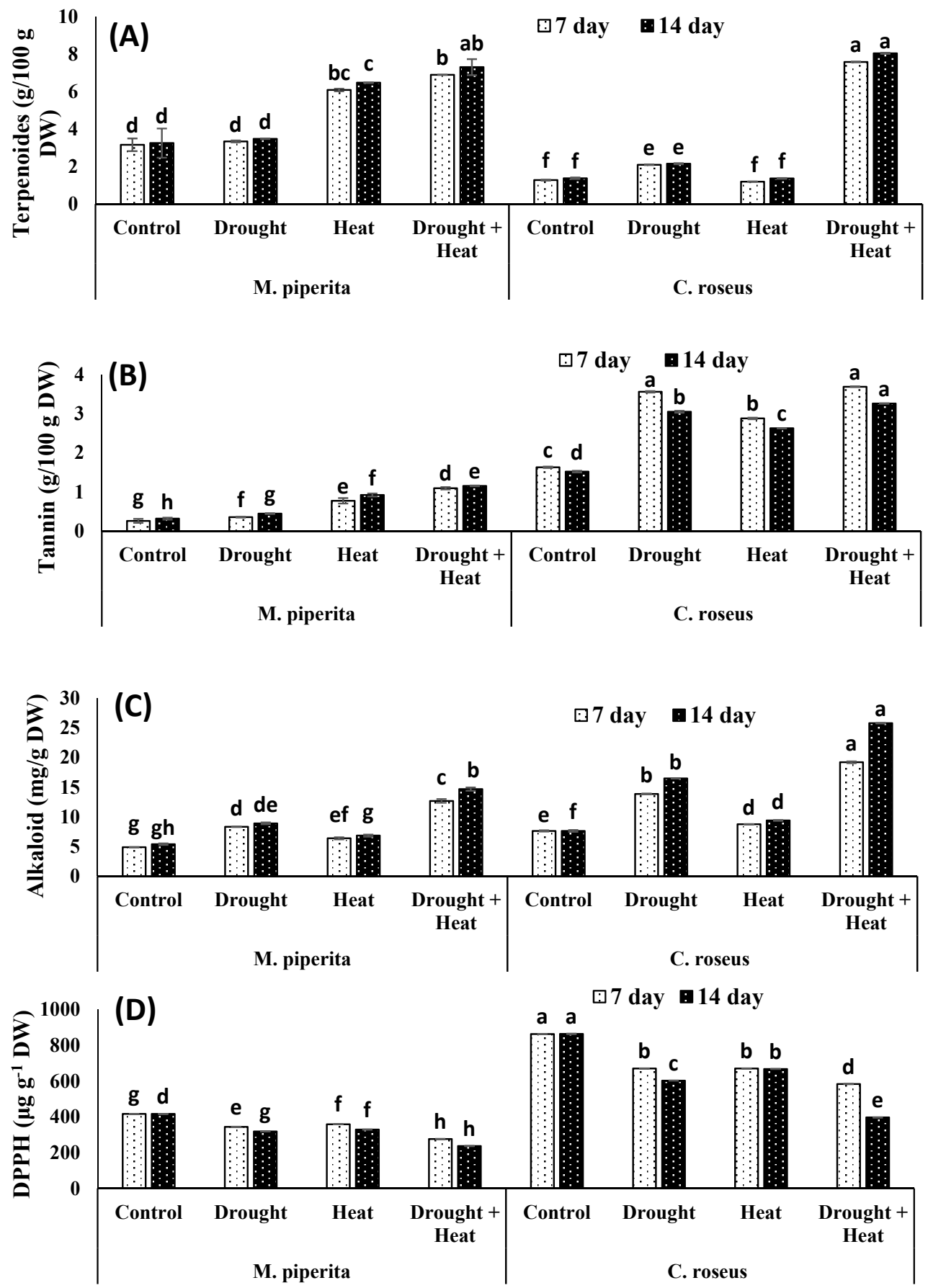

Figure 4. Effect of drought, heat and drought + heat stress on the terpenoids (A), tannins (B), alkaloids (C) and DPPH scavenging activities (D) in M. piperita and C. roseus after seven and fourteen days of stress exposure. Mean $( \pm \mathrm{SE})$ of five values is presented and values denoted by different letters are significantly different at $p<0.05$.

At both developmental stages (i.e., at seven and fourteen days), secondary metabolite accumulations increased. Secondary metabolites include an array of useful natural products that form important components of plant defense systems to counteract the deleterious effects of environmental stresses $[12,67,68]$. These metabolites have remarkable biological activities and are often exploited as medicinal and food ingredients for therapeutic, aromatic, and culinary purposes [68]. Increased accumulation of secondary metabolites prevents the oxidative effects of drought stress on the membrane structure and imparts greater pharmacological properties to plants [69]. Drought stress influences the accumulation of key secondary metabolites, including phenols and flavonoids, in Amaranthus [70]. 
In contrast to our results, Gharibi et al. [69] recently demonstrated increased accumulation of flavonoids and expression of flavonoid biosynthesis genes in Achillea pachycephala after prolonged exposure to drought; the overall effect enhanced oxidative stress due to the increased accumulation of ROS like $\mathrm{H}_{2} \mathrm{O}_{2}$. Under stress conditions, the accumulation of secondary metabolites helps plants to modulate their response mechanisms as these substances act as key signaling components [71,72]. Increased accumulation of metabolites under stress conditions protects the structural and functional aspects of membranes and cells [72].

In contrast to our results, Liu et al. [73] demonstrated an increased accumulation of alkaloids and the expression of genes regulating secondary metabolite accumulation in drought-stressed C. roseus. However, reports discussing the combined effects of drought and heat stress on the accumulation of secondary metabolites are rare. Accumulation of secondary metabolites, including isoprenoids, alkaloids, and phenolics, under stressful conditions occurs due to the oversupply of NADPH + $\mathrm{H}+[72,74,75]$. In the present study, both plant species exhibited significant accumulations of alkaloids, which presumably play similar roles in drought and heat tolerance as they do in other plants. Plant terpenoids function in a variety of growth and development processes under normal and stress environments [76]. Genes regulating the shikimic acid pathway and the biosynthesis of alkaloids like anthocyanins and lignin are up-regulated in response to stress [77]. In Betula pendula and Populus tremula, Ibrahim et al. [78] demonstrated increased accumulation of terpenoids at elevated temperatures. In Pinus radiata, Escandón et al. [79] demonstrated that the accumulation of secondary metabolites, including flavonoids and terpenoids, is regulated by zeatin riboside and isopentenyl adenosine. The piperita and C. roseus growing under control conditions shown to be more efficient in scavenging DPPH free radicals and had a higher reducing power than those exposed to drought and heat stress. This finding provides evidence that tissues of piperita and C. roseus subjected to heat and/or drought stress contain less antioxidants and reducing compounds. Król and his co-author [80] and Zainol et al. [81] proved that the phenolic compounds are the main contributors to the scavenging activities. The degree of antioxidative impact generated by phenols mostly relies on the structure of provided compound and particularly on the amount and distribution of hydroxyl groups $(-\mathrm{OH})$. Antioxidative activity is substantially greater if a compound has two -OH groups in the ortho position [82].

\subsection{Effects of Drought and Heat Stress on the Antibacterial, Antifungal, and Anticancer Activities of the Extracts of $M$. piperita and $C$. roseus}

Both plant species were tested for their medicinal efficacy against certain potentially pathogenic fungal and bacterial species and cancer cell lines. Both aqueous and methanolic extracts of M. piperita and C. roseus significantly inhibited the growth of bacterial and fungal species, and they both substantially suppressed the growth of cancerous cell lines. The effects on growth of P. aeruginosa, S. aureus and $R$. solanacearum were most apparent at higher extract concentrations (20\%), with the effect much more obvious against $S$. aureus. When compared to $M$. piperita extracts, the $C$. roseus extracts were more effective at inhibiting bacterial growth (Table 3). The aqueous and methanolic extracts of $M$. piperita and C. roseus also significantly inhibited the growth of fungal species like A. terreus. Again, methanolic extracts were more effective than the aqueous extracts, and the inhibitory effect was concentration dependent, increasing with higher concentrations (Table 4). The results also showed that drought and heat stress significantly reduced the growth inhibition of bacterial and fungal species, and thus reduced the antimicrobial activities and quality of plant species (Tables 3 and 4).

The extracts of both plant species suppressed the growth of cancerous cells and again showed a concentration dependence with both the aqueous and the methanolic extracts. The inhibitory effect was more much evident in the PC3 cell line, and the C. roseus extracts were more effective than the M. piperita extracts. The methanol extracts were also more effective than the aqueous extracts at suppressing cancer cell growth (Table 5). The results also showed that drought and heat stress significantly decreased cancer inhibition, and thus reduced the anticancer activities and quality of plants (Table 5). 
Table 3. Diameter of inhibition zone ( $\mathrm{mm}$ ) of M. piperita and C. roseus against three pathogenic bacterial isolates under control and 14 day stress conditions.

\begin{tabular}{|c|c|c|c|c|c|c|c|c|c|c|c|}
\hline \multirow{2}{*}{ Bacterial Strain } & \multirow{2}{*}{ Plants } & \multirow{2}{*}{ Treatment } & \multicolumn{2}{|c|}{ Control } & \multicolumn{2}{|c|}{ Drought } & \multicolumn{2}{|c|}{ Heat } & \multicolumn{2}{|c|}{ Drought + Heat } & \multirow{2}{*}{$\begin{array}{c}0.2 \mu \mathrm{g} / \mathrm{mL} \\
\text { Ampicillin }\end{array}$} \\
\hline & & & $10 \%$ & $20 \%$ & $10 \%$ & $20 \%$ & $10 \%$ & $20 \%$ & $10 \%$ & $20 \%$ & \\
\hline \multirow{4}{*}{ P. aeruginosa } & \multirow{2}{*}{ M. piperita } & Aqueous & $13 \pm 0.23 \mathrm{~d}$ & $18 \pm 0.27 b$ & $11 \pm 0.24 \mathrm{f}$ & $15 \pm 0.21 c$ & $10 \pm 0.12 \mathrm{~g}$ & $12 \pm 0.11 \mathrm{e}$ & $12 \pm 0.24 \mathrm{e}$ & $11 \pm 0.24 \mathrm{f}$ & $32 \pm 0.21 \mathrm{a}$ \\
\hline & & $\mathrm{MeOH}$ & $15 \pm 0.17 \mathrm{e}$ & $20 \pm 0.24 b$ & $14 \pm 0.21 \mathrm{f}$ & $18 \pm 0.24 \mathrm{c}$ & $12 \pm 0.17 \mathrm{~g}$ & $17 \pm 0.22 \mathrm{~d}$ & $11 \pm 0.21 \mathrm{~h}$ & $17 \pm 0.22 \mathrm{~d}$ & $36 \pm 0.22 a$ \\
\hline & \multirow{2}{*}{ C. roseus } & Aqueous & $16 \pm 0.25 \mathrm{e}$ & $27 \pm 0.21 \mathrm{a}$ & $14 \pm 0.22 \mathrm{f}$ & $24 \pm 0.24 b$ & $12 \pm 0.21 \mathrm{~g}$ & $21 \pm 0.22 c$ & $12 \pm 0.21 \mathrm{~g}$ & $22 \pm 0.21 c$ & $19 \pm 0.24 \mathrm{~d}$ \\
\hline & & $\mathrm{MeOH}$ & $14 \pm 0.27 \mathrm{e}$ & $31 \pm 0.22 b$ & $12 \pm 0.21 \mathrm{f}$ & $27 \pm 0.21 c$ & $9 \pm 0.11 \mathrm{~h}$ & $24 \pm 0.26 \mathrm{~d}$ & $10 \pm 0.26 \mathrm{~g}$ & $23 \pm 0.22 \mathrm{~d}$ & $37 \pm 0.25 a$ \\
\hline \multirow{4}{*}{ S. aureus } & \multirow{2}{*}{ M. piperita } & Aqueous & $12 \pm 0.31 \mathrm{f}$ & $19 \pm 0.29 b$ & $11 \pm 0.25 \mathrm{~g}$ & $16 \pm 0.22 c$ & $10 \pm 0.21 \mathrm{~g}$ & $14 \pm 0.25 \mathrm{~d}$ & $8 \pm 0.22 \mathrm{~h}$ & $13 \pm 0.24 \mathrm{e}$ & $38 \pm 0.22 a$ \\
\hline & & $\mathrm{MeOH}$ & $16 \pm 0.18 \mathrm{e}$ & $25 \pm 0.27 \mathrm{~b}$ & $13 \pm 0.24 \mathrm{f}$ & $21 \pm 0.23 c$ & $12 \pm 0.24 \mathrm{~g}$ & $20 \pm 0.21 c$ & $10 \pm 0.21 \mathrm{~h}$ & $18 \pm 0.21 \mathrm{~d}$ & $30 \pm 0.21 \mathrm{a}$ \\
\hline & \multirow{2}{*}{ C. roseus } & Aqueous & $23 \pm 0.22 \mathrm{e}$ & $36 \pm 0.26 \mathrm{a}$ & $20 \pm 0.22 \mathrm{f}$ & $32 \pm 0.25 b$ & $17 \pm 0.27 \mathrm{~g}$ & $29 \pm 0.22 c$ & $15 \pm 0.25 \mathrm{~h}$ & $27 \pm 0.22 \mathrm{~d}$ & $27 \pm 0.22 \mathrm{~d}$ \\
\hline & & $\mathrm{MeOH}$ & $25 \pm 0.27 \mathrm{f}$ & $37 \pm 0.22 \mathrm{a}$ & $23 \pm 0.27 \mathrm{~g}$ & $34 \pm 0.24 \mathrm{~b}$ & $20 \pm 0.21 \mathrm{~h}$ & $30 \pm 0.25 \mathrm{~d}$ & $19 \pm 0.22 \mathrm{i}$ & $31 \pm 0.25 c$ & $27 \pm 0.21 \mathrm{e}$ \\
\hline \multirow{4}{*}{ R. solanacearum } & \multirow{2}{*}{ M. piperita } & Aqueous & $18 \pm 0.24 c$ & $23 \pm 0.18 a$ & $15 \pm 0.22 \mathrm{e}$ & $20 \pm 0.26 b$ & $14 \pm 0.24 \mathrm{e}$ & $18 \pm 0.24 c$ & $14 \pm 0.21 \mathrm{e}$ & $17 \pm 0.22 \mathrm{~d}$ & $24 \pm 0.21 \mathrm{a}$ \\
\hline & & $\mathrm{MeOH}$ & $19 \pm 0.26 \mathrm{~d}$ & $26 \pm 0.32 \mathrm{a}$ & $18 \pm 0.22 \mathrm{e}$ & $24 \pm 0.24 b$ & $16 \pm 0.26 \mathrm{f}$ & $21 \pm 0.22 c$ & $17 \pm 0.22 \mathrm{f}$ & $22 \pm 0.21 c$ & $27 \pm 0.25 \mathrm{a}$ \\
\hline & \multirow{2}{*}{ C. roseus } & Aqueous & $15 \pm 0.21 \mathrm{f}$ & $25 \pm 0.33 b$ & $13 \pm 0.21 \mathrm{~g}$ & $23 \pm 0.22 c$ & $11 \pm 0.25 \mathrm{~h}$ & $20 \pm 0.21 \mathrm{~d}$ & $10 \pm 0.21 \mathrm{i}$ & $19 \pm 0.22 \mathrm{e}$ & $28 \pm 0.14 a$ \\
\hline & & $\mathrm{MeOH}$ & $22 \pm 0.25 c$ & $26 \pm 0.31 b$ & $20 \pm 0.27 \mathrm{~d}$ & $22 \pm 0.22 c$ & $17 \pm 0.21 \mathrm{e}$ & $23 \pm 0.22 c$ & $15 \pm 0.24 \mathrm{f}$ & $20 \pm 0.24 \mathrm{~d}$ & $28 \pm 0.21 \mathrm{a}$ \\
\hline
\end{tabular}

Mean ( \pm SE) of five values is presented and values denoted by different letters are significantly different at $p<0.05$.

Table 4. Effect of different concentrations of $0.5 \%$ and $1.0 \%$ (v:v) of M. piperita and C. roseus Aqueous and methanolic extracts on the growth of $F$. oxysporum and A. terreus under control and 14 day stress conditions. Mean diameters are expressed in $\mathrm{mm}$.

\begin{tabular}{|c|c|c|c|c|c|c|c|c|c|c|c|}
\hline \multirow{2}{*}{ Fungal Strain } & \multirow{2}{*}{ Plants } & \multirow{2}{*}{ Treatment } & \multicolumn{2}{|c|}{ Control } & \multicolumn{2}{|c|}{ Drought } & \multicolumn{2}{|c|}{ Heat } & \multicolumn{2}{|c|}{ Drought + Heat } & \multirow{2}{*}{ Rhizolex-T } \\
\hline & & & $0.5 \%$ & $1.0 \%$ & $0.5 \%$ & $1.0 \%$ & $0.5 \%$ & $1.0 \%$ & $0.5 \%$ & $1.0 \%$ & \\
\hline \multirow{2}{*}{ F. oxysporum } & M. piperita & $\begin{array}{c}\text { Aqueous } \\
\mathrm{MeOH}\end{array}$ & $\begin{array}{l}74 \pm 0.92 \mathrm{e} \\
58 \pm 0.87 \mathrm{f}\end{array}$ & $\begin{array}{c}72 \pm 0.46 \mathrm{f} \\
53 \pm 0.92 \mathrm{~g}\end{array}$ & $\begin{array}{l}77 \pm 0.76 \mathrm{c} \\
64 \pm 0.79 \mathrm{~d}\end{array}$ & $\begin{array}{l}75 \pm 0.65 \mathrm{~d} \\
61 \pm 0.85 \mathrm{e}\end{array}$ & $\begin{array}{l}79 \pm 0.87 b \\
67 \pm 0.83 b\end{array}$ & $\begin{array}{l}78 \pm 0.77 b \\
63 \pm 0.81 d\end{array}$ & $\begin{array}{l}80 \pm 0.43 a \\
69 \pm 0.85 a\end{array}$ & $\begin{array}{l}78 \pm 0.76 b \\
65 \pm 0.91 c\end{array}$ & \multirow{2}{*}{$48.6 \pm 0.55$} \\
\hline & C. roseus & $\begin{array}{c}\text { Aqueous } \\
\mathrm{MeOH}\end{array}$ & $\begin{array}{l}52 \pm 0.68 \mathrm{e} \\
47 \pm 0.54 \mathrm{e}\end{array}$ & $\begin{array}{l}46 \pm 0.64 \mathrm{f} \\
43 \pm 0.86 \mathrm{f}\end{array}$ & $\begin{array}{l}56 \pm 0.92 \mathrm{~d} \\
52 \pm 0.75 \mathrm{~d}\end{array}$ & $\begin{array}{l}53 \pm 0.86 \mathrm{e} \\
47 \pm 0.83 \mathrm{e}\end{array}$ & $\begin{array}{l}61 \pm 0.91 b \\
56 \pm 0.85 c\end{array}$ & $\begin{array}{l}56 \pm 0.66 d \\
50 \pm 0.73 c\end{array}$ & $\begin{array}{l}63 \pm 0.72 a \\
59 \pm 0.91 a\end{array}$ & $\begin{array}{l}60 \pm 0.86 c \\
57 \pm 0.74 b\end{array}$ & \\
\hline \multirow{2}{*}{ A. terreus } & M. piperita & $\begin{array}{l}\text { Aqueous } \\
\mathrm{MeOH}\end{array}$ & $\begin{array}{l}63 \pm 0.76 \mathrm{e} \\
60 \pm 0.73 \mathrm{~d}\end{array}$ & $\begin{array}{l}60 \pm 0.93 \mathrm{f} \\
56 \pm 0.38 \mathrm{f}\end{array}$ & $\begin{array}{l}68 \pm 0.76 c \\
66 \pm 0.67 c\end{array}$ & $\begin{array}{l}64 \pm 0.76 \mathrm{~d} \\
59 \pm 0.65 \mathrm{e}\end{array}$ & $\begin{array}{l}70 \pm 0.64 b \\
69 \pm 0.97 b\end{array}$ & $\begin{array}{l}67 \pm 0.83 c \\
67 \pm 0.86 c\end{array}$ & $\begin{array}{l}74 \pm 0.82 a \\
73 \pm 0.59 a\end{array}$ & $\begin{array}{l}70 \pm 0.76 b \\
69 \pm 0.92 b\end{array}$ & \multirow{2}{*}{$26.6 \pm 0.43$} \\
\hline & C. roseus & $\begin{array}{c}\text { Aqueous } \\
\mathrm{MeOH}\end{array}$ & $\begin{array}{l}64 \pm 0.48 \mathrm{e} \\
60 \pm 0.89 \mathrm{f}\end{array}$ & $\begin{array}{l}53 \pm 0.86 \mathrm{f} \\
56 \pm 0.74 \mathrm{~g}\end{array}$ & $\begin{array}{l}68 \pm 0.92 \mathrm{~d} \\
67 \pm 0.54 \mathrm{~d}\end{array}$ & $\begin{array}{l}64 \pm 0.87 \mathrm{e} \\
64 \pm 0.76 \mathrm{e}\end{array}$ & $\begin{array}{l}71 \pm 0.65 b \\
69 \pm 0.85 b\end{array}$ & $\begin{array}{l}69 \pm 0.92 c \\
67 \pm 0.76 d\end{array}$ & $\begin{array}{l}73 \pm 0.23 a \\
71 \pm 0.67 a\end{array}$ & $\begin{array}{l}71 \pm 0.81 b \\
68 \pm 0.73 c\end{array}$ & \\
\hline
\end{tabular}

Mean ( \pm SE) of five values is presented and values denoted by different letters are significantly different at $p<0.05$. 
Table 5. Percentage of inhibition (\%) of PC3 and MCF-7 cancer cell lines exposed to different concentrations (50 and $100 \mu \mathrm{g} / \mathrm{mL})$ of M. piperita and C. roseus aqueous and methanolic extracts under control and 14 day stress conditions.

\begin{tabular}{|c|c|c|c|c|c|c|c|c|c|c|}
\hline \multirow{2}{*}{ Cell Lines } & \multirow{2}{*}{ Plants } & \multirow{2}{*}{ Treatment } & \multicolumn{2}{|c|}{ Control } & \multicolumn{2}{|c|}{ Drought } & \multicolumn{2}{|c|}{ Heat } & \multicolumn{2}{|c|}{ Drought + Heat } \\
\hline & & & $50 \mu \mathrm{g} / \mathrm{mL}$ & $100 \mu \mathrm{g} / \mathrm{mL}$ & $50 \mu \mathrm{g} / \mathrm{mL}$ & $100 \mu \mathrm{g} / \mathrm{mL}$ & $50 \mu \mathrm{g} / \mathrm{mL}$ & $100 \mu \mathrm{g} / \mathrm{mL}$ & $50 \mu \mathrm{g} / \mathrm{mL}$ & $100 \mu \mathrm{g} / \mathrm{mL}$ \\
\hline \multirow{4}{*}{ PC3 } & \multirow{2}{*}{ M. piperita } & Aqueous & $56 \pm 0.76 b$ & $64 \pm 0.72 \mathrm{a}$ & $48 \pm 0.71 \mathrm{e}$ & $53 \pm 0.77 c$ & $43 \pm 0.43 \mathrm{f}$ & $50 \pm 0.43 \mathrm{~d}$ & $44 \pm 0.88 \mathrm{f}$ & $48 \pm 0.51 \mathrm{e}$ \\
\hline & & $\mathrm{MeOH}$ & $50 \pm 0.83 b$ & $65 \pm 0.82 \mathrm{a}$ & $44 \pm 0.62 \mathrm{~d}$ & $47 \pm 0.82 \mathrm{c}$ & $41 \pm 0.75 \mathrm{e}$ & $43 \pm 0.76 \mathrm{~d}$ & $38 \pm 0.54 \mathrm{f}$ & $41 \pm 0.44 \mathrm{e}$ \\
\hline & \multirow{2}{*}{ C. roseus } & Aqueous & $46 \pm 0.59 c$ & $61 \pm 0.81 \mathrm{a}$ & $42 \pm 0.73 \mathrm{e}$ & $47 \pm 0.77 \mathrm{~b}$ & $39 \pm 0.73 \mathrm{f}$ & $44 \pm 0.83 \mathrm{~d}$ & $37 \pm 0.77 \mathrm{~g}$ & $42 \pm 0.54 \mathrm{e}$ \\
\hline & & $\mathrm{MeOH}$ & $38 \pm 0.73 \mathrm{~d}$ & $56 \pm 0.73 a$ & $35 \pm 0.71 \mathrm{e}$ & $42 \pm 0.82 b$ & $33 \pm 0.82 \mathrm{~g}$ & $38 \pm 0.84 \mathrm{~d}$ & $34 \pm 0.82 \mathrm{f}$ & $39 \pm 0.76 c$ \\
\hline \multirow{4}{*}{ MCF-7 } & \multirow{2}{*}{ M. piperita } & Aqueous & $63 \pm 0.83 c$ & $81 \pm 0.62 a$ & $57 \pm 0.55 \mathrm{f}$ & $65 \pm 0.73 b$ & $53 \pm 0.47 \mathrm{~g}$ & $61 \pm 0.81 \mathrm{~d}$ & $51 \pm 0.77 \mathrm{~h}$ & $59 \pm 0.82 \mathrm{e}$ \\
\hline & & $\mathrm{MeOH}$ & $53 \pm 0.81 c$ & $72 \pm 0.81 \mathrm{a}$ & $50 \pm 0.65 \mathrm{e}$ & $56 \pm 0.76 b$ & $47 \pm 0.92 \mathrm{~g}$ & $52 \pm 0.82 \mathrm{~d}$ & $49 \pm 0.43 \mathrm{f}$ & $49 \pm 0.57 \mathrm{f}$ \\
\hline & \multirow{2}{*}{ C. roseus } & Aqueous & $60 \pm 0.73 \mathrm{~d}$ & $74 \pm 0.62 \mathrm{a}$ & $55 \pm 0.82 \mathrm{e}$ & $70 \pm 0.82 b$ & $52 \pm 0.82 \mathrm{f}$ & $64 \pm 0.65 c$ & $49 \pm 0.76 \mathrm{~g}$ & $60 \pm 0.74 \mathrm{~d}$ \\
\hline & & $\mathrm{MeOH}$ & $45 \pm 0.61 \mathrm{e}$ & $67 \pm 0.71 \mathrm{a}$ & $41 \pm 0.56 \mathrm{f}$ & $62 \pm 0.84 b$ & $37 \pm 0.65 \mathrm{~g}$ & $57 \pm 0.84 \mathrm{c}$ & $36 \pm 0.45 \mathrm{~h}$ & $54 \pm 0.76 \mathrm{~d}$ \\
\hline
\end{tabular}

Mean $( \pm \mathrm{SE})$ of five values is presented and values denoted by different letters are significantly different at $p<0.05$. 
Singh et al. [83] have also demonstrated a significant inhibitory effect of peppermint extract on the growth of certain gram positive and gram-negative bacteria. The antibacterial and antifungal activities of M. piperita are ascribed to presence of the essential oil and other key phytochemical components. Traditionally, peppermint and its oil have been used medicinally for their antispasmodic, antiseptic, and aromatic properties and in the treatment of colds, nausea, cancers, cramps, indigestion, sore throat, and toothache $[83,84]$. Peppermint oil exhibits in vitro antibacterial activity, and various commercial preparations show beneficial activities [85]. Peppermint also exhibits antiviral and fungicidal activities [86]. Peppermint has been reported to reduce the incidence and multiplicity of lung carcinogenicity and mutagenicity [87].

The polyphenolic compounds present in plants are considered to impart their medicinal properties. Among the key polyphenolic compounds with biologically active roles are the hydroxycinnamic acids (HCAs), such as caffeic, p-coumaric, ferulic, and rosmarinic acids. These compounds account for one-third of the total polyphenolics in plants and are responsible for major functions [88]. The medical and other related pharmaceutical functions of these active compounds are ascribed to their protective activity of preventing oxidative damage due to excess ROS [89]. Recently, Alexa et al. [90] have demonstrated a considerable inhibition of the MDA-MB-231 breast carcinoma cell line and the A375 human melanoma cell line, as well as antimicrobial activity against $S$. aureus, due to presence of certain key HCAs in Mentha piperita L. and Lavandula angustifolia. In present study, both M. piperita and C. roseus species showed significant presence of phytochemicals including phenols, flavonoids, tannins, and alkaloids.

The current results indicated that $C$. roseus provides antibacterial activity. The extracts displayed antibacterial activity by exhibiting zones of inhibitions versus the pathogenic microorganisms utilized in the study. Plants are a vital resource of several key compounds of medicinal and pharmaceutical importance, and plant-derived medicines have a far higher molecular diversity than synthetic drugs [91]. The presence of alkaloids in C. roseus reflects its medicinal activity, including anticancer activity [92]. It has been previously proposed that the existence of flavonoids in the leaf of $C$. roseus may consider its remarkably high radical scavenging activity $[93,94]$. The presences of these phytochemicals in plants (terpenoids, tannins, alkaloids) display an excellent relationship for the antimicrobial activities of the plants [95]. Moon et al. [96] demonstrated the anticancer activity of $C$. roseus against the human renal cell carcinoma Caki-2 cell line and a non-cancer MDCK cell line from Madin-Darby canine kidneys, and they attributed this effective anticancer activity to the presence of bioactive compounds and the terpenoid indole acetic acid. Drought and heat stress significantly reduced the antimicrobial and anticancer activities of plant extracts in the present study. This result could be attributed to the reduction in phenolics and flavonoids contents recorded under drought and heat stress.

\section{Conclusions}

Drought and heat stress significantly decreased growth and biomass accumulation in Mentha piperita and Catharanthus roseus. Increased accumulation of osmolytes and secondary metabolites at early and late growth stages in response to stress confirmed the potential of these compounds to counteract the deleterious effects of drought and heat stress. The accumulation of osmolytes and secondary metabolites may contribute to the maintenance of growth under stress conditions by improving the plant water potential and increasing ROS scavenging, thereby preventing the damaging effects of drought and heat stress. Aqueous and methanolic extracts of both plant species showed significant antibacterial, antifungal, and anticancer activity, confirming the promising medicinal potential of these two plants.

Author Contributions: H.A.A., M.H.S., K.L.A., M.A.E.-E. and A.E. carried out the experiments, analyzed the data and wrote the manuscript. All authors have read and agreed to the published version of the manuscript.

Funding: This research received no external funding.

Conflicts of Interest: The authors declare no conflict of interest. 


\section{References}

1. Jakada, B.H.; Aslam, M.; Fakher, B.; Greaves, J.G.; Li, Z.; Li, W.; Lai, L.; Ayoade, O.A.; Cheng, Y.; Cao, S.; et al. Identification of SWI2/SNF2-Related 1 Chromatin Remodeling Complex (SWR1-C) Subunits in Pineapple and the Role of Pineapple SWR1 COMPLEX 6 (AcSWC6) in Biotic and Abiotic Stress Response. Biomolecules 2019, 9, 364. [CrossRef] [PubMed]

2. Li, X.; Guo, C.; Ahmad, S.; Wang, Q.; Yu, J.; Liu, C.; Guo, Y. Systematic Analysis of MYB Family Genes in Potato and Their Multiple Roles in Development and Stress Responses. Biomolecules 2019, 9, 317. [CrossRef] [PubMed]

3. El-Esawi, M.A.; Al-Ghamdi, A.A.; Ali, H.M.; Ahmad, M. Overexpression of AtWRKY30 Transcription Factor Enhances Heat and Drought Stress Tolerance in Wheat (Triticum aestivum L.). Genes 2019, 10, 163. [CrossRef] [PubMed]

4. El-Esawi, M.A.; Alayafi, A.A. Overexpression of StDREB2 Transcription Factor Enhances Drought Stress Tolerance in Cotton (Gossypium barbadense L.). Genes 2019, 10, 142. [CrossRef]

5. El-Esawi, M.A.; Alayafi, A.A. Overexpression of Rice Rab7 Gene Improves Drought and Heat Tolerance and Increases Grain Yield in Rice (Oryza sativa L.). Genes 2019, 10, 56. [CrossRef]

6. El-Esawi, M.A.; Alaraidh, I.A.; Alsahli, A.A.; Alamri, S.A.; Ali, H.M.; Alayafi, A.A. Bacillus firmus (SW5) augments salt tolerance in soybean (Glycine max L.) by modulating root system architecture, antioxidant defense systems and stress-responsive genes expression. Plant. Physiol. Biochem. 2018, 132, 375-384. [CrossRef]

7. El-Esawi, M.A.; Al-Ghamdi, A.A.; Ali, H.M.; Alayafi, A.A. Azospirillum lipoferum FK1 confers improved salt tolerance in chickpea (Cicer arietinum L.) by modulating osmolytes, antioxidant machinery and stress-related genes expression. Environ. Exp. Bot. 2019, 159, 55-65. [CrossRef]

8. Elkelish, A.A.; Alnusaire, T.S.; Soliman, M.H.; Gowayed, S.; Senousy, H.H.; Fahad, S. Calcium availability regulates antioxidant system, physio-biochemical activities and alleviates salinity stress mediated oxidative damage in soybean seedlings. J. Appl. Bot. Food Qual. 2019, 92, 258-266.

9. Elkeilsh, A.; Awad, Y.M.; Soliman, M.H.; Abu-Elsaoud, A.; Abdelhamid, M.T.; El-Metwally, I.M. Exogenous application of $\beta$-sitosterol mediated growth and yield improvement in water-stressed wheat (Triticum aestivum) involves up-regulated antioxidant system. J. Plant. Res. 2019, 132, 881-901. [CrossRef]

10. Ahmad, P.; Ahanger, M.A.; Egamberdieva, D.; Alam, P.; Alyemeni, M.N.; Ashraf, M. Modification of Osmolytes and Antioxidant Enzymes by 24-Epibrassinolide in Chickpea Seedlings under Mercury $(\mathrm{Hg})$ Toxicity. J. Plant Growth Regul. 2018, 37, 309-322. [CrossRef]

11. Bennett, R.N.; Wallsgrove, R.M. Secondary metabolites in plant defence mechanisms. New Phytol. 1994, 127, 617-633. [CrossRef]

12. Yang, L.; Wen, K.S.; Ruan, X.; Zhao, Y.X.; Wei, F.; Wang, Q. Response of Plant Secondary Metabolites to Environmental Factors. Molecules 2018, 23, 762. [CrossRef] [PubMed]

13. Zandalinas, S.I.; Mittler, R.; Balfagón, D.; Arbona, V.; Gómez-Cadenas, A. Plant adaptations to the combination of drought and high temperatures. Physiol. Plant. 2018, 162, 2-12. [CrossRef] [PubMed]

14. Alhaithloul, H.A.S. Impact of Combined Heat and Drought Stress on the Potential Growth Responses of the Desert Grass Artemisia sieberi alba: Relation to Biochemical and Molecular Adaptation. Plants 2019, 8, 416. [CrossRef]

15. Elansary, H.O.; Szopa, A.; Kubica, P.; Ekiert, H.; Ali, H.M.; Elshikh, M.S.; Abdel-Salam, E.M.; El-Esawi, M.; El-Ansary, D.O. Bioactivities of traditional medicinal plants in Alexandria. Evid. Based. Complement. Altern. Med. 2018, 2018, 1463579. [CrossRef]

16. El-Esawi, M.A.; Elkelish, A.; Elansary, H.O.; Ali, H.M.; Elshikh, M.; Witczak, J.; Ahmad, M. Genetic Transformation and Hairy Root Induction Enhance the Antioxidant Potential of Lactuca serriola L. Available online: https://www.hindawi.com/journals/omcl/2017/5604746/ (accessed on 9 January 2018).

17. Elkelish, A.A.; Soliman, M.H.; Alhaithloul, H.A.; El-Esawi, M.A. Selenium protects wheat seedlings against salt stress-mediated oxidative damage by up-regulating antioxidants and osmolytes metabolism. Plant Physiol. Biochem. 2019, 137, 144-153. [CrossRef]

18. Abdel-Daim, M.M.; Abdou, R.H. Protective Effects of Diallyl Sulfide and Curcumin Separately against Thallium-Induced Toxicity in Rats. Cell J. 2015, 17, 379-388. 
19. Abdel-Daim, M.M.; El-Ghoneimy, A. Synergistic protective effects of ceftriaxone and ascorbic acid against subacute deltamethrin-induced nephrotoxicity in rats. Ren. Fail. 2015, 37, 297-304. [CrossRef]

20. Abdel-Daim, M.M.; Zakhary, N.I.; Aleya, L.; Bungǎu, S.G.; Bohara, R.A.; Siddiqi, N.J. Aging, Metabolic, and Degenerative Disorders: Biomedical Value of Antioxidants. Oxidative Med. Cell. Longev. 2018, 2018, 2098123. [CrossRef]

21. Yeung, A.W.K.; Tzvetkov, N.T.; El-Tawil, O.S.; Bungǎu, S.G.; Abdel-Daim, M.M.; Atanasov, A.G. Antioxidants: Scientific Literature Landscape Analysis. Available online: https://www.hindawi.com/journals/omcl/2019/ 8278454/ (accessed on 16 June 2019).

22. Elkelish, A.A.; Alhaithloul, H.A.S.; Qari, S.H.; Soliman, M.H.; Hasanuzzaman, M. Pretreatment with Trichoderma harzianum alleviates waterlogging-induced growth alterations in tomato seedlings by modulating physiological, biochemical, and molecular mechanisms. Environ. Exp. Bot. 2019, 171, 103946. [CrossRef]

23. Herro, E.; Jacob, S.E. Mentha piperita (peppermint). Dermatitis 2010, 21, 327-329. [CrossRef] [PubMed]

24. Nair, B. Final report on the safety assessment of Mentha Piperita (Peppermint) Oil, Mentha Piperita (Peppermint) Leaf Extract, Mentha Piperita (Peppermint) Leaf, and Mentha Piperita (Peppermint) Leaf Water. Int. J. Toxicol. 2001, 20, 61-73. [PubMed]

25. Diouf, B.; Crews, K.R.; Lew, G.; Pei, D.; Cheng, C.; Bao, J.; Zheng, J.J.; Yang, W.; Fan, Y.; Wheeler, H.E.; et al. Association of an inherited genetic variant with vincristine-related peripheral neuropathy in children with acute lymphoblastic leukemia. JAMA 2015, 313, 815-823. [CrossRef] [PubMed]

26. Bradford, M.M. A rapid and sensitive method for the quantitation of microgram quantities of protein utilizing the principle of protein-dye binding. Anal. Biochem. 1976, 72, 248-254. [CrossRef]

27. Troll, W.; Lindsley, J. A photometric method for the determination of proline. J. Biol Chem 1955, 215, 655-660.

28. Grieve, C.M.; Grattan, S.R. Rapid assay for determination of water soluble quaternary ammonium compounds. Plant. Soil 1983, 70, 303-307. [CrossRef]

29. Irigoyen, J.J.; Einerich, D.W.; Sanchez-Diaz, M. Water stress induced changes in concentrations of proline and total soluble sugars in nodulated alfalfa (Medicago sativd) plants. Physiol. Plant. 1992, 84, 55-60. [CrossRef]

30. Slinkard, K.; Singleton, V.L. Total Phenol Analysis: Automation and Comparison with Manual Methods. Am. J. Enol Vitic. 1977, 28, 49-55.

31. Julkunen-Tiitto, R. Phenolic constituents in the leaves of northern willows: Methods for the analysis of certain phenolics. J. Agric. Food Chem. 1985, 33, 213-217. [CrossRef]

32. Jia, Z.; Tang, M.; Wu, J. The determination of flavonoid contents in mulberry and their scavenging effects on superoxide radicals. Food Chem. 1999, 64, 555-559.

33. Obadoni, B.O.; Ochuko, P.O. Phytochemical studies and comparative efficacy of the crude extracts of some haemostatic plants in Edo and Delta States of Nigeria. Glob. J. Pure Appl. Sci. 2002, 8, 203-208. [CrossRef]

34. Ferguson, N.M. A Textbook of Pharmacognosy; Macmillan Company: New York, NY, USA, 1956.

35. Amadi, B.A.; Agomuo, E.N.; Ibegbulem, C.O. Proximate analysis. In Research Methods in Biochemistry; Supreme Publishers: Owerri, Nigeria, 2004; pp. 105-115.

36. Ezeonu, C.S.; Eboatu, A.N.; Ejikeme, C. Determination of Physical and Phytochemical Constituents of some Tropical Timbers Indigenous to nigerdelta area of nigeria. Eur. Sci. J. 2014, 10, 247-270.

37. Harborne, A.J. Phytochemical Methods a Guide to Modern Techniques of Plant Analysis; Springer: Dordrecht, The Netherlands, 1998.

38. Espín, J.C.; Soler-Rivas, C.; Wichers, H.J. Characterization of the total free radical scavenger capacity of vegetable oils and oil fractions using 2,2-diphenyl-1-picrylhydrazyl radical. J. Agric. Food Chem. 2000, 48, 648-656. [CrossRef] [PubMed]

39. Romijn, J.C.; Verkoelen, C.F.; Schroeder, F.H. Application of the MTT assay to human prostate cancer cell lines in vitro: Establishment of test conditions and assessment of hormone-stimulated growth and drug-induced cytostatic and cytotoxic effects. Prostate 1988, 12, 99-110. [CrossRef]

40. Cerrudo, D.; González Pérez, L.; Mendoza Lugo, J.A.; Trachsel, S. Stay-Green and Associated Vegetative Indices to Breed Maize Adapted to Heat and Combined Heat-Drought Stresses. Remote Sens. 2017, 9, 235. [CrossRef]

41. Perera, R.S.; Cullen, B.R.; Eckard, R.J. Growth and Physiological Responses of Temperate Pasture Species to Consecutive Heat and Drought Stresses. Plants 2019, 8, 227. [CrossRef] 
42. Ahanger, M.A.; Agarwal, R.M. Salinity stress induced alterations in antioxidant metabolism and nitrogen assimilation in wheat (Triticum aestivum L) as influenced by potassium supplementation. Plant. Physiol. Biochem. 2017, 115, 449-460. [CrossRef]

43. Saleh, A.A.H.; Abdel-Kader, D.; El Kelish, A. Role of Heat Shock and Salicylic Acid in Antioxidant Homeostasis in Mungbean (Vigna radiata L.) Plant Subjected to Heat Stress. Am. J. Plant. Physiol. 2007, 2, 344-355.

44. Sita, K.; Sehgal, A.; Bhandari, K.; Kumar, J.; Kumar, S.; Singh, S.; Siddique, K.H.; Nayyar, H. Impact of heat stress during seed filling on seed quality and seed yield in lentil (Lens culinaris Medikus) genotypes. J. Sci. Food Agric. 2018, 98, 5134-5141. [CrossRef]

45. Sehgal, A.; Sita, K.; Bhandari, K.; Kumar, S.; Kumar, J.; Vara Prasad, P.V.; Siddique, K.H.; Nayyar, H. Influence of drought and heat stress, applied independently or in combination during seed development, on qualitative and quantitative aspects of seeds of lentil (Lens culinaris Medikus) genotypes, differing in drought sensitivity. Plant Cell Environ. 2019, 42, 198-211. [CrossRef]

46. Sehgal, A.; Sita, K.; Kumar, J.; Kumar, S.; Singh, S.; Siddique, K.H.; Nayyar, H. Effects of Drought, Heat and Their Interaction on the Growth, Yield and Photosynthetic Function of Lentil (Lens culinaris Medikus) Genotypes Varying in Heat and Drought Sensitivity. Front. Plant. Sci. 2017, 8, 1776. [CrossRef] [PubMed]

47. Francis-West, P.; Ladher, R.; Barlow, A.; Graveson, A. Signalling interactions during facial development. Mech. Dev. 1998, 75, 3-28. [CrossRef]

48. Rymen, B.; Fiorani, F.; Kartal, F.; Vandepoele, K.; Inzé, D.; Beemster, G.T. Cold nights impair leaf growth and cell cycle progression in maize through transcriptional changes of cell cycle genes. Plant. Physiol. 2007, 143, 1429-1438. [CrossRef] [PubMed]

49. Slama, I.; Abdelly, C.; Bouchereau, A.; Flowers, T.; Savoure, A. Diversity, distribution and roles of osmoprotective compounds accumulated in halophytes under abiotic stress. Ann. Bot. 2015, 115, 433-447. [CrossRef]

50. Pade, N.; Hagemann, M. Salt Acclimation of Cyanobacteria and Their Application in Biotechnology. Life 2014, 5, 25-49. [CrossRef]

51. Sharma, A.; Shahzad, B.; Kumar, V.; Kohli, S.K.; Sidhu, G.P.S.; Bali, A.S.; Handa, N.; Kapoor, D.; Bhardwaj, R.; Zheng, B. Phytohormones Regulate Accumulation of Osmolytes under Abiotic Stress. Biomolecules 2019, 9, 285. [CrossRef]

52. Hare, P.D.; Cress, W.A.; Van Staden, J. Dissecting the roles of osmolyte accumulation during stress. Plant Cell Environ. 1998, 21, 535-553. [CrossRef]

53. Parry, M.A.J.; Andralojc, P.J.; Scales, J.C.; Salvucci, M.E.; Carmo-Silva, A.E.; Alonso, H.; Whitney, S.M. Rubisco activity and regulation as targets for crop improvement. J. Exp. Bot 2013, 64, 717-730. [CrossRef]

54. Akhtar, M.S. Salt Stress, Microbes, and Plant. Interactions: Mechanisms and Molecular Approaches; Springer: Singapore, 2019; ISBN 9789811388057.

55. Kishor, P.K.; Sangam, S.; Amrutha, R.N.; Laxmi, P.S.; Naidu, K.R.; Rao, K.; Rao, S.; Reddy, K.J.; Theriappan, P.; Sreenivasulu, N. Regulation of proline biosynthesis, degradation, uptake and transport in higher plants: Its implications in plant growth and abiotic stress tolerance. Curr. Sci. 2005, 88, 424-438.

56. Spaans, S.K.; Weusthuis, R.A.; Van Der Oost, J.; Kengen, S.W.M. NADPH-generating systems in bacteria and archaea. Front. Microbiol. 2015, 6, 742. [CrossRef]

57. Mohammadkhani, N.; Heidari, R. Drought-induced Accumulation of Soluble Sugars and Proline in Two Maize Varieties. World Appl. Sci. J. 2008, 6, 448-453.

58. Iqbal, N.; Umar, S.; Khan, N.A. Nitrogen availability regulates proline and ethylene production and alleviates salinity stress in mustard (Brassica juncea). J. Plant. Physiol. 2015, 178, 84-91. [CrossRef] [PubMed]

59. Harsh, A.; Sharma, Y.K.; Joshi, U.; Rampuria, S.; Singh, G.; Kumar, S.; Sharma, R. Effect of short-term heat stress on total sugars, proline and some antioxidant enzymes in moth bean (Vigna aconitifolia). Ann. Agric. Sci. 2016, 61, 57-64. [CrossRef]

60. Kaushal, S.S.; Belt, K.T. The urban watershed continuum: Evolving spatial and temporal dimensions. Urban Ecosyst. 2012, 15, 409-435. [CrossRef]

61. Giri, J. Glycinebetaine and abiotic stress tolerance in plants. Plant. Signal. Behav. 2011, 6, $1746-1751$. [CrossRef]

62. El-Esawi, M.A.; Al-Ghamdi, A.A.; Ali, H.M.; Alayafi, A.A.; Witczak, J.; Ahmad, M. Analysis of genetic variation and enhancement of salt tolerance in French pea. Int. J. Mol. Sci. 2018, 19, 2433. [CrossRef] 
63. El-Esawi, M.A.; Alaraidh, I.A.; Alsahli, A.A.; Ali, H.M.; Alayafi, A.A.; Witczak, J.; Ahmad, M. Genetic Variation and Alleviation of Salinity Stress in Barley (Hordeum vulgare L.). Molecules 2018, 23, 2488. [CrossRef]

64. van Gelderen, K.; Kang, C.; Pierik, R. Light Signaling, Root Development, and Plasticity. Plant Physiol. 2018, 176, 1049-1060. [CrossRef]

65. Ahanger, M.A.; Tomar, N.S.; Tittal, M.; Argal, S.; Agarwal, R.M. Plant growth under water/salt stress: ROS production; antioxidants and significance of added potassium under such conditions. Physiol. Mol. Biol. Plants 2017, 23, 731-744. [CrossRef]

66. Keunen, E.; Peshev, D.; Vangronsveld, J.; Van Den Ende, W.; Cuypers, A. Plant sugars are crucial players in the oxidative challenge during abiotic stress: Extending the traditional concept: Sugars and abiotic stress. Plant Cell Environ. 2013, 36, 1242-1255. [CrossRef]

67. Abbas, F.; Ke, Y.; Yu, R.; Yue, Y.; Amanullah, S.; Jahangir, M.M.; Fan, Y. Volatile terpenoids: Multiple functions, biosynthesis, modulation and manipulation by genetic engineering. Planta 2017, 246, 803-816. [CrossRef] [PubMed]

68. Ahmad, B.; Jahan, A.; Sadiq, Y.; Shabbir, A.; Jaleel, H.; Khan, M.M.A. Radiation-mediated molecular weight reduction and structural modification in carrageenan potentiates improved photosynthesis and secondary metabolism in peppermint (Mentha piperita L.). Int. J. Biol. Macromol. 2019, 124, 1069-1079. [CrossRef] [PubMed]

69. Gharibi, N.; Kailass, K.; Beharry, A.A. Exploiting the Cellular Redox-Control System for Activatable Photodynamic Therapy. ChemBioChem 2019, 20, 345-349. [CrossRef] [PubMed]

70. Sarker, U.; Oba, S. Drought stress enhances nutritional and bioactive compounds, phenolic acids and antioxidant capacity of Amaranthus leafy vegetable. BMC Plant Biol. 2018, 18, 258. [CrossRef] [PubMed]

71. Akula, R.; Ravishankar, G.A. Influence of abiotic stress signals on secondary metabolites in plants. Plant Signal. Behav. 2011, 6, 1720-1731. [CrossRef] [PubMed]

72. Franzoni, G.; Trivellini, A.; Bulgari, R.; Cocetta, G.; Ferrante, A. Chapter 10-Bioactive Molecules as Regulatory Signals in Plant Responses to Abiotic Stresses. In Plant Signaling Molecules; Khan, M.I.R., Reddy, P.S., Ferrante, A., Khan, N.A., Eds.; Woodhead Publishing: Cambridge, UK, 2019; pp. 169-182. ISBN 978-0-12-816451-8.

73. Liu, Y.; Meng, Q.; Duan, X.; Zhang, Z.; Li, D. Effects of PEG-induced drought stress on regulation of indole alkaloid biosynthesis in Catharanthus roseus. J. Plant. Interact. 2017, 12, 87-91. [CrossRef]

74. Kleinwächter, M.; Selmar, D. New insights explain that drought stress enhances the quality of spice and medicinal plants: Potential applications. Agron. Sustain. Dev. 2015, 35, 121-131. [CrossRef]

75. Nantongo, J.S.; Odoi, J.B.; Abigaba, G.; Gwali, S. Variability of phenolic and alkaloid content in different plant parts of Carissa edulis Vahl and Zanthoxylum chalybeum Engl. BMC Res. Notes 2018, 11, 125. [CrossRef]

76. Tholl, D. Biosynthesis and Biological Functions of Terpenoids in Plants. In Biotechnology of Isoprenoids; Schrader, J., Bohlmann, J., Eds.; Advances in Biochemical Engineering/Biotechnology; Springer International Publishing: Cham, Switzerland, 2015; pp. 63-106. ISBN 978-3-319-20107-8.

77. Karlic, H.; Thaler, R.; Gerner, C.; Grunt, T.; Proestling, K.; Haider, F.; Varga, F. Inhibition of the mevalonate pathway affects epigenetic regulation in cancer cells. Cancer Genet. 2015, 208, 241-252. [CrossRef]

78. Ibrahim, M.A.; Maenpaa, M.; Hassinen, V.; Kontunen-Soppela, S.; Malec, L.; Rousi, M.; Pietikainen, L.; Tervahauta, A.; Karenlampi, S.; Holopainen, J.K.; et al. Elevation of night-time temperature increases terpenoid emissions from Betula pendula and Populus tremula. J. Exp. Bot. 2010, 61, 1583-1595. [CrossRef]

79. Escandón, M.; Meijón, M.; Valledor, L.; Pascual, J.; Pinto, G.; Cañal, M.J. Metabolome Integrated Analysis of High-Temperature Response in Pinus radiata. Front. Plant. Sci. 2018, 9, 485. [CrossRef] [PubMed]

80. Król, A.; Amarowicz, R.; Weidner, S. Changes in the composition of phenolic compounds and antioxidant properties of grapevine roots and leaves (Vitis vinifera L.) under continuous of long-term drought stress. Acta Physiol. Plant 2014, 36, 1491-1499.

81. Zainol, M.K.; Abd-Hamid, A.; Yusof, S.; Muse, R. Antioxidative activity and total phenolic compounds of leaf, root and petiole of four accessions of Centella asiatica (L.) Urban. Food Chem. 2003, 81, 575-581. [CrossRef]

82. Rosicka-Kaczmarek, J. Polifenole jako naturalne antyoksydanty w zywnosci. Przeglad Piek. I Cukier. 2004, 6, $12-16$.

83. Singh, R.; Shushni, M.A.M.; Belkheir, A. Antibacterial and antioxidant activities of Mentha piperita L. Arab. J. Chem. 2015, 8, 322-328. [CrossRef] 
84. Jirovetz, L.; Buchbauer, G.; Bail, S.; Denkova, Z.; Slavchev, A.; Stoyanova, A.; Schmidt, E.; Geissler, M. Antimicrobial Activities of Essential Oils of Mint and Peppermint as Well as Some of Their Main Compounds. J. Essent. Oil Res. 2009, 21, 363-366. [CrossRef]

85. Aparna, L.M.; Aparna, S.; Sarada, I.; Ram, D. Assessment of Sputum Quality and Its Importance in the Rapid Diagnosis of Pulmonary Tuberculosis. Arch. Clin. Microbiol. 2017, 8. [CrossRef]

86. Bupesh, G.; Amutha, C.; Nandagopal, S.; Ganeshkumar, A.; Sureshkumar, P.; Murali, K. Antibacterial activity of Mentha piperita L. (peppermint) from leaf extracts-A medicinal plant. Acta Agric. Slov. 2007, 89, 73-79. [CrossRef]

87. Samarth, R.M.; Panwar, M.; Kumar, M.; Kumar, A. Protective effects of Mentha piperita Linn on benzo[a]pyrene-induced lung carcinogenicity and mutagenicity in Swiss albino mice. Mutagenesis 2006, 21, 61-66. [CrossRef]

88. Adaszyńska-Skwirzyńska, M.; Dzięcioł, M. Comparison of phenolic acids and flavonoids contents in various cultivars and parts of common lavender (Lavandula angustifolia) derived from Poland. Nat. Prod. Res. 2017, 31, 2575-2580. [CrossRef]

89. Spiridon, I.; Colceru, S.; Anghel, N.; Teaca, C.A.; Bodirlau, R.; Armatu, A. Antioxidant capacity and total phenolic contents of oregano (Origanum vulgare), lavender (Lavandula angustifolia) and lemon balm (Melissa officinalis) from Romania. Nat. Prod. Res. 2011, 25, 1657-1661. [CrossRef] [PubMed]

90. Alexa, E.; Danciu, C.; Radulov, I.; Obistioiu, D.; Sumalan, R.M.; Morar, A.; Dehelean, C.A. Phytochemical Screening and Biological Activity of Mentha $\times$ piperita L. and Lavandula angustifolia Mill. Extracts. Anal. Cell. Pathol. 2018, 2018, 1-7. [CrossRef] [PubMed]

91. Surendra, K.C.; Olivier, R.; Tomberlin, J.K.; Jha, R.; Khanal, S.K. Bioconversion of organic wastes into biodiesel and animal feed via insect farming. Renew. Energy 2016, 98, 197-202. [CrossRef]

92. Arora, R.; Malhotra, P.; Mathur, A.; Mathur, A. Anticancer Alkaloids of Catharanthus roseus: Transition from Traditional to Modern Medicine. In Herbal Medicine: A Cancer Chemopreventive and Therapeutic Perspective; Jaypee Brothers Medical Publishers (P) Ltd.: New Delhi, India, 2010; p. 292. ISBN 978-81-8448-841-8.

93. Naz, S.; Haq, R.; Aslam, F.; Ilyas, S. Evaluation of antimicrobial activity of extracts of in vivo and in vitro grown Vinca rosea L. (Catharanthus roseus) against pathogens. Pak. J. Pharm. Sci. 2015, 28, 849-853. [PubMed]

94. Fa, O.; Et, O.; Io, O.; Ef, O. Antimicrobial activity and phytochemical screening of leaf extracts of catharantus roseus against aspergillus niger. Int. J. Pure Appl. Zool. 2019, 7. [CrossRef]

95. Raza, M.L.; Nasir, M.; Abbas, T.; Naqvi, B.S. Antibacterial activity of different extracts from the Catharanthus roseus. Clin. Exp. Med. J. 2009, 3, 81-85. [CrossRef]

96. Moon, S.H.; Pandurangan, M.; Kim, D.H.; Venkatesh, J.; Patel, R.V.; Mistry, B.M. A rich source of potential bioactive compounds with anticancer activities by Catharanthus roseus cambium meristematic stem cell cultures. J. Ethnopharmacol. 2018, 217, 107-117. [CrossRef] 